\title{
The Origin of Affixes.
}

\author{
AG(iLI'TINATION.
}

The oldest and best-known theory of the origin of affixes is the agglutination theory. Such a genesis of affixes has also been proved in very many cases. An allxiliary word becomes unaccented in syntagme, becoming pro- or enclitic, and forming a phonetic unit with the principal word, subjected to the phenomena of sandhi and assimilation, and finally merging into one word with the principal word. The former auxiliary word usually weakens phonetically and grows shorter. In this way, e.g. some case endings originate from postpositions, such as the Estonian comitative suffix -ga< kaas < haasa 'with'. In the same way some conjugation suffixes originate from auxiliary verbs, e.g. French future (je) dirai < Latin dicere habeo. The grammaticization of autonomous words into auxiliary words as well as the reduction of auxiliary words into affixes takes place gradually. We often find intermediate stages where it is difficult to state whether we have to do with an anxiliary word or with an affix (cf. e.g. D.L. R. Lorimer BI, 53). Thus the same element in a language may be called postposition by some authors. and suffix by others. The most consistent representative of the agglutination theory in the 20 th century is A. Cuny. according to whom auxiliary words form the origin not only of all suffixes, prefixes and infixes, but also of all polysyllabic stems, the latter having sprung into existence through the agglutination of the so-called "full" and sempty" words (cf. e.g. EP 2:39 note $2,446-, 450-$ ). Learing aside the question of the origin of polysyllabic stems, it should be stressed with regard to the origin of affixes that, no matter how great a part agglutination 
may have had in the origin of morphology, it is by no means the only mode of genesis of suffixes (cf. K. Brugmann K 284-, G. Royen NKS 467, 468, C. Meinhof EFS 32). The number of suffixes whose origin has been proved to be due to agghtination is, however, relatively small when compared with the total number of suffixes. ${ }^{1}$ A plausible assumption is that a great number of prefixes originate in igglutination (see e.g. concerning Indo-European prefixes Brugmann $\mathrm{K} 284$, as to Siamese, K. Wulff ChT 209), but as far as the languages of the Far East are concerned H. Maspero, e.g. thinks that the Mon-Khmer and Munda languages employ prefixes that have certainly never been words, and he thinks it probable that the same also applies to Tibetan-Burman prefixes ( $\mathrm{LM}^{2}$ 534). As to the history of the agghtination theory, see e.g. J. Schmidt $\mathrm{Ny} 384-$. The opinion that the flexional affixes, especially Indo-European flexional suffixes, originate mainly through agglutination from former auxiliary words, is even at present rather widely spread among linguists (of the newer authors see e.g. A. Drexel UWS II 190). Of the Finno-Ugric linguists L. Kettunen is of the opinion that in principle a word of originally fixed signification ought to be assumed behind the flexional suffixes (EK 1940 251). Concerning criticism of the aggintination theory see e.g. (). Jespersen I, $367^{--}$.

\section{ADAPTATION AND SECRETION.}

\section{History.}

The adaptation theory came into existence as a counterbalance to the one-sided agglutination theory in attempts to solve the problem of the origin of Indo-European flexion. The initiator of this theory was A. Ludwig ("Agglutination oder Adaptation", 1873). Ludwig does not reject agglutination, but

1 Examples of agglutination from various language-families will be given by the author in his so far unpublished work "The Structural Tendencies of Languages". 
his new guiding idea is that suffixes were not added to the roots and stems uin $\mathrm{der}$ bedeut u $\mathrm{ng}$. i n welcher wir sie fungieren sehen" (AOA 24), and that "flexion selbst einst nicht flexion war" (AoA 112). This is the first essential thesis of the adaptation theory. This thesis applies especially to flexional suffixes, i.e. flexional suffixes had not from the beginning a flexional function, but acquired it later on. This applies properly speaking to all morphemes, and in a comprehensive sense we might call every grammaticization adaptation. inasmuch as the origin of every grammatical category and morpheme means an "reinterpretation" (umdeutung) of lexical elements as grammatical (cf. W. Porzig Atti 290).

If this thesis is accepted as correct, the question arises: what did the flexional suffixes express originally before they had acquired their flexional function? Ludwig's thesis is here: "die suffixe modificieren ursprünglich die bedeutung von wurzel oder stamm gar nicht, sie gaben beziehungen nach aussen" (AoA 27). According to Ludwig the development of grammar has followed the following scheme: 1 . In the beginning there were only roots. 2. Some roots degenerated into deictic pronouns. 3. These agglntinated with the roots, and the word came into existence. 4. The deictic signification of the agglutimated elements disappeared. and they were transformed into derivational suffixes. 5. Derivational suffixes were transformed into flexional suffixes (SKAW 55 134). In this scheme of development the last stage is of the greatest importance and of the most lasting ralue. since the second important thesis of Ludwig's theory, which has to be recognized even at the present. is: "zwischen wortbildung und flexion besteht keine absolute ursprüngliche rerschiedenheit, letztere ist nur eine weiterentwicklung der ersteren" (AoA 115).

Ludwig's theory did not, when first published, meet with any approval worth mentioning. Ludwig s contemporary, G. Curtius, expressed the opinion that Indo-European nominative and accusative endings were of pronominal origin, and that before having been transformed into flexional morphemes they had occurred in the function of derivational suffixes. The Sanscrit 
renitive endings -sja and -as and the ablative -at have also. formerly been derivational suffixes (Ch 71 - ). Another of Ludwig's contemporaries, A. Bergaigne, also thought that a great part of the Indo-European flexional suffixes and coaffixes were originally derivational suffixes (MSL 2358 ). R. de la Grasserie assumed, contrary to Ludwig. that the function of derivational suffixes is primary. that later on derivational suffixes were transformed into demonstrative suffixes and pronouns and. after having passed that intermediary stage. developed into flexional suffixes (C $230-$.)

In $1905 \mathrm{H}$. Oertel and E. P. Morris of Yale University. published an article in defence of Ludwig's adaptation theory (HS 16), their main aroument in benefit of adaptation and against the (semantic) agglutination being the difference between the regular and systematic "agglutinating" Ural-Altaic languages and the sflective" Indo-European languages with their irregular and unsystematic structure. which latter trait they thought might be explained only by adaptation.

In 1910 J. Schmidt made it his task to rehabilitate Ludwir. finding that this was a debt of honour the Indo-European linguists owed him ( $\mathrm{Ny} \quad 3 \quad 81-)$. Schmidt quite correctly points out that a few established cases of auglutination which are known from historical time, are always used to support the agglutination theory. whereas the enormous number of indubitable instances of adaptation are scarcely ever mentioned. or only quite casually. Schmidt shows rightly that modern linguistic research, consciously or unconsciously. proceeds from the adaptation theory when interpreting the facts in the various Indo-European languages. Schmidt calls attention in the first place to the following generally recognized phenomena $(\mathrm{Ny}+21-$ ): the morphologic interpretation of alternations, such as metaphony, gemination and sentence phonetic doublets (such as English my:mine), metanalytic and syntactic displacements (e.g. German währendes lirieges > während des livieges), various changes of function (such as Frenc on $<$ Latin homo). Schmidt shows further how the adaptation theory so far actually has been employed in the domain of suffixes. Here Schmidt calls attention to the following generally 
known phenomena, presenting abundant instances from the Indo-European languages: secondary functions of nominal derivational suffixes (e.g. the so-called phenomena of stem irradiation), secondary functions of flexional suffixes (e.g. when a case or verb form acquires the function of another case or verb form), the transformation of final parts of stems or of derivational suffixes into flexional suffixes (the so-called phenomena of secretion), e.g. the origination of plural signs like the English oxen, or the nominal origin of some IndoEuropean personal morphemes (e.g. in the imperative).

Schmidt maintains that these facts of adaptation. which have come abont in historical time, oblige us to apply the same principle to the prehistoric Indo-European Proto-language too. Furthermore Schmidt shows that these phenomena of adaptation which have come about in historical time are a continuation of tendencies that were present in prehistoric languages and in the Indo-European Proto-language. Schmidt presents numerous instances where modern linguistic research has actually applied the principle of adaptation in explaining such prehistoric linguistic facts as the origin of genders, the different functions of cases fof which schmidt draws the conclusion that the case forms in the beginning had no signification) $(\mathrm{Ny}+121)$, cases withult suffixes (nominatives, rocatives, locatives), the case functions of nondeclensional elements (e.g. the i-element in the Italian-Celtic genitive and in the Indo-European singular feminine was originally a derivative suffix), the various functions of verb forms, the identity of nominal and rerbal stems, the phenomenon that verbo-nominal suffixes were originally parts of stems that had no meaning, and that acquired their functions first through adaptation (e.g. the verbo-nominal $\bar{c}$-element is the final part. of bisyllabic "heavy" stems). Schmidt concludes on the basis of these explanations made by Indo-European linguistic research up to now that adaptation is the typical form of the Indo-European flexional development, and that nothing else can be done but renew Ludwig's theory with the means of modern linguistic research.

Schmidt is of the opinion that, in explaining the Indo- 
European flexion, H. Hirt's particle theory (see below) must be certainly dropped as the last remnant of the theory of semantic agglutination ( $\mathrm{Ny}+188$ ). Schmidt's standpoint resembles that of Jespersen: Indo-European flexion has not developed from monosyllabic roots but from unanalyzable and undifferentiated primitive sound continuums of complex meaning. Derivational suffixes were the first suffixed elements that originated from this development, the meaningless endings of verbonominal bases having adapted the functions of derivational suffixes, of whose priority over flexional suffixes Schmidt is fully convinced. It was not until after the genesis of derivational suffixes that the flexional suffixes developed, the derivational suffixes or stem endings acquiring, under the influence of syntactic relations, the functions of flexion. Flexion that had arisen in this way spread by analogy and formal agglutination. The nominal and verbal flexion are identical, but the former is older, as verbal flexion together with personal endings has evolved from nominal flexion by means of adaptation.

As regards other older authors who to a greater or smaller rxtent have expressed standpoints based on the adaptation principle, see Schmidt $\mathrm{Ny}+185$ -

During the present century the adaptation theory has gained more and more supporters. It has been applied most extensively by H. Hirt, who is of the opinion that adaptation has played the most important part in the genesis of Indo-European flexion. According to Hirt a great number of suffixes originate in a coalescence of words and deictic particles, which had more or less the same character as French celui-ci, celui-la (IG $385-, 164-, 180-)$. In the beginning the addition of these particles did not essentially change the meaning of the words. Later on these agclutinated particles acquired the function of derivational and flexional suffixes. According to Hirt all IndoEuropean cases originate from such »determinatives». Criticism of Hirt's exaggerated theory of adaptation and determinatives, see Jespersen Lo 382-, H. Koppelmann ES 12-. F. Specht, too, is of the opinion that all Indo-European case suffixes originate from the stems of demonstrative pronouns that had 
coalesced with nouns. though these case endings originally had nothing in common with their subsequent syntactic function (UID 353-, 391). M. Vasmer agrees in principle with Schmidt's thesis, and calls attention to Westermann's personal statement that Nubian case endings, too, are explicable by pronominal origin. According to Vasmer the question is only whether all case and derivational suffixes treated by Specht may be explained in this way (ZSPh 19 444). In the opinion of E. Locker: "Auftrefois, les génitifs, locatifs ainsi que les pluriels n'étaient pas de formes de déclinaison d'un même substantif, mais des noms d'appartenance, de liel, de collectifs indépendants. dérivés d'un autre nom. La transformation du système vague de la formation de mots dans un système fixe de flexion est dûe à un développement secondaire." In the same way the different stems of conjugation categories of the verb also had in the beginning a lexical function, and first later on were transformed into flexional categories (WBKL 9 423). The adaptation theory in the sense of Ludwig and Hirt has also been applied by S. W. F. Margadant to explain the IndoEuropean verb forms. According to Margadant tense suffixes had in the beginning no meaning, being only emphatic elements (Actes II 200).

In Finno-Uwric linguistics the importance of adaptation as a principle of the genesis of grammatical elements, especially in Hungarian, has been emphasized by the Hungarian scientist J. Melich (A magyar tárọyas igreragozás, Budapest 1914), Z. Gombocz (UJb 102 ) and A. Klemm (ME 155). The latter agrees with J.Schmidt's theory. Of the Finno-Ugric linguists J. Beronka contests the adaptation theory as a principle of the origin of case suffixes, being of the opinion that case suffixes are certainly former words (LK 12i). Lately the adaptation theory has gained ground also among Finnish linguists. P. Ravila has come near Ludwig's theory, having adopted the same standpoint as Ludwig that 1) primary flexional suffixes have acquired their meaning through adaptation from connections in the sentence; 2) primary flexional suffixes have earlier been derivational suffixes: 3) the primary function of derivational suffixes has been to connect words; 
they were a certain kind of preflexional elements of construction (cf. A. Belič's more or less similar standpoint concerning the Indo-European suffixes, Atti 287, cf. G. J. Ramstedt JSFOu $5595-)$; 4) derivational suffixes have formerly been pronouns (see further Vir. 1945 158. 314-, and here below 211). In fact, D. Bubrih and T. E. Uotila also agree with the adaptation theory, assuming that several primary case suffixes were formerly derivational suffixes (see below $200-$ ). The Hungarian scientist Gy. Lakó, proceeding from Ravila's hypothesis, assumes especially that the Uralic locative suffixes ${ }^{*} n z$ and ${ }^{*}-t$ originate from the agglutination of demonstrative pronouns begimning with $n$ - and $t$ - with nouns (ALH 1354 -, MTAK 1 213-). J. Farkas, too, thinks that the primary FU case suffixes, which precede possessive suffixes, were originally derivational suffixes (UAJb 26 59). Regarding the Turkish language $\mathrm{K}$. Frönbech is of the opinion that "die ältesten konkreten Kasus höchst wahrscheinlich von Haus aus keine Kasusformen, sondern abgeleitete nomina concreta waren, wie dies im Monglischen noch zum Teil der Fall zu sein scheint. Diese Annahme führt uns in eine Zeit zurück, wo das Prinzip der grammatischen Rektion noch nicht existierte" (TS 145). A. v. Tabain is of the opinion that the Turkish case endings, with the exception of accusative, are partly derived from derivational suffixes, partly from postpositions (ATG 151; see also especially concerning the locative $\mathrm{S} \cap 14: 57$-; cf. also the connecting of the Yakut derivational suffix $-t i$ with the locative-ablative suffix, K. Schriefl KSz 13 283). According to H. Vogt the Old-Georgian genitive suffix $-i s$, instrumental suffix - $i t$, adverbial case suffix $-a d$ and plural oblique case suffix -et were originally derivational suffixes (NTS 14 136).

With the adaptation theory is also connected the secretion theory of which Jespersen is the main representative ( $\operatorname{Lg} 384-$ ). By secretion Jespersen understands the phenomenon that one portion of an originally indivisible word comes to acquire a grammatical signification which it had not at first. Secretion thus is a consequence of a metanalysis. Secretion shows its full force when the part of a word thus secreted through metanalysis comes to be added to other words not originally 12 - Finnisch-ugrische Forschungen 
possessing this element. Thus in secretion adaptation or interpretetation also occur. Secretion theory differs from adaptation theory only in so far that the latter assumes that the interpreted elements of words originate from agglutination, whereas the former supposes secretion or metanalysis. As instances of secretion Jespersen presents, among others, the English plural ending -en in oxen and German -er, which originally was part of the stem in a word such as rind: rinder, but which through secretion acquired the meaning of plural ending and spread to words where it originally did not belong. like wörter, brïder.

Jespersen notices that a trait highly characteristic of secretion is that (seen from the point of view of the speaker) the occurrence of endings originating in this way seems accidental: they occur in some words, but not in others. The endings originating in agglutination, on the contrary, occur more uniformly and are added to all words. But as a similar irregular or arbitrary distribution is met with in the case of nearly all flexional endings in the oldest stages of the Indo-European languages, Jespersen is of the opinion that this circumstance concurs with the assumption that most of the Indo-European suffixes, the origin of which we do not know, originated by secretion or similar processes. rather than by agglutination (cf. the point of view of Oertel and Morris above 173). According to Jespersen the great majority of derivational as well as of flexional suffixes can be traced back to such beginnings. The suffix separated hy secretion. when added to new words. acquired a certain coloming from these words, and gradually acquired an independent signifiration and a special function of its own (Lg 391).

How was secretion possible at a language stage when there as yet were no grammatical categories and morphemes at all, which might have served as analogy? Jespersen maintains that man is a classifying animal and that the whole process of language is nothing but distributing phenomena into different classes on the strength of similarities. Jespersen presents an instance related by Professor Hempl whose daughter, when having received a black kitten called Nig, immediately called a gray kitten Grig and a brown one Brounig. Her' we see 
the genesis of a suffix, says Jespersen. The classifying instinct often manifests itself in bringing words together in forms which have something in common as regards meaning. In this way there are smaller classes and larger classes, of which it is sometimes impossible to say in what way their similarity in form has come about. E.g. in Old English some names of animals have the ending -gga, such as frogga, stagga, docga, wicga, now frog, stag, dog, wig. Jespersen gives other similar instances. ( $\mathrm{Lg} 388-$-).

W. Wundt has also expressed a similar riew regarding the genesis of nominal derivational suffixes in Part II of $"$ Die Sprache». Wundt says: "Wie die Komparationsformen ursprünglich aller Wahrscheinlichkeit nach nicht Grad-, sondern Artunterschiede sind, so erscheint die Sprache überhaupt ursprünglich erfüllt von Unterscheidungen der Gegenstände und Eigenschaften, bei denen das Verwandte oder ähnlich Erscheinende durch lautliche Angleichung verknüpft wird. Dabei geschieht diese Angleichung regelmässig so, dass die Grundelemente des Wortes zunächst den individuellen Begriffsinhalt ausdrücken. während Beziehungselemente, die als Suffixe oder Präfixe zu ihnen hinzutreten, und die für eine bestimmte Regriffsklasse übereinstimmend sind, die Art oder Gattung bezeichnen, welcher der Begriff angehürt. So weichen die uralten indogermanischen Verwandtschaftsnamen Tater, Mutter, Bruder, schwester, Tochter, schwager in ihren die spezielle Bedeutung tragenden Lautbestandsteilen sämtlich voneinander ab; aber durch die übereinstimmende Endung sind sie zu einer Gruppe verbunden. Mit dieser Endung muss sich daher in einer frühen Zeit die Vorstellung der Verwandtschaft rerknüpft haben. Sicherlich ist das nach allem, was wir über die Vorgänge der Berriffsbildung wissen, nicht so geschehen, dass sofort für eine solche Gruppe von Wörtern ein derartiges, die Begriffsklasse verzeichnendes Suffix auf einmal entstand. Die psychologisch einzig mögliche Weise, sich den Vorgang zu denken, besteht viel mehr darin, dass von der Bildung eines Verwandtschaftsnamens zu der eines anderen eine Assoziation der beiden Vorstellungen und der sie begleitenden Gefühle herüberreichte, welche eine Angleichung derjenigen Lautele- 
mente des Wortes bewirkte, die nicht dem Ausdruck des besonderen Inhalts der Vorstellung dienten" (15-; cf. also H. Oertel LSL $60-$, Brugmann K 313). The difference between Jespersen and Wundt consists in Wundt's apparently being of the opinion that derivational suffixes originate by agoglutination, and not by secretion (cf. e.g. op.cit. 18).

The opinion that the Indo-European suffixes have not originated by agglutination has grown more and more general during the present century (ef. e.g. J. Kuryłowic\%. EI 131). In connection with this the secretion theory has come into more extensive use, especially in explaining the genesis of Indo-European flexion (see e.g. Royen NKS 502, Meinhof EFS 32, W. Porzig Atti 290, Kurylowicz EI 131). Already Brugmann admitted the possibility of secretion (K 313). (For instances of secretion in Indo-European and other languages. see Royen $498-506){ }^{1}$

Relationship of Case Suffixes and Derivational Suffixes.

Ludwig's thesis that the flexional suffixes originally had some function of a different kind. is supported by numerous historical facts from various languages. It is a generally known phenomenon that the meaning of affixes changes in the same way as the meaning of words. Change of meaning can be observed in derivational as well as flexional suffixes. As regards flexional suffixes it is e.g. known that cases change their meaning. Beronka says: "Die Entwicklung der lappischen Kasus zeigt, dass mehrere ihrer Suffixe sich mit grosser Iıeichtigkeit

1 In Finno-Ugric linguistics the secretion theory has been applied to explain the origin of derivational suffixes by A. Rytkönen in his work "Eräiden itämerensuomen tm-sanojen historiaa" (1940). Rỵtkönen is of the opinion that e.g. suffixes $-m a,-j a,-k a,-l a,-p a,-t a / \sim-m \ddot{a}$. $-j \ddot{a},-k \ddot{a},-l \ddot{a},-p \ddot{a},-t \ddot{a})$ may have originated by secretion from words of onomatopoetic type pim:pima, hui: huja, äkä, helä(htäa), kop : kopa(htaa), kit: kita(jaa) (29-; for criticism of the investigation, see A. Penttilä Vir. $1940246-$, esp. 253). 
neuen Bedeutungen angepasst haben, dieser Adaption scheint die Grundbedeutung kein wesentliches Hindernis gewesen $\mathrm{zu}$ sein" (LK 129).

Changes of meaning, however, do not occur only within the limits of one and the same grammatical category, as history of language presents abundant instances where, e.g. derivational suffixes have been changed into flexional suffixes. Even the transformation of originally autonomous words into auxiliary words (morphemes) proves that the bounds between lexical and flexional elements are not insurmountable. The same is proved by the circumstance that often it is impossible with some language elements to say whether we are concerned with a lexeme (semanteme) or a morpheme, a stem or an affix (Boas HAIL I 34--; B. Malinorski MoM 302: cf. W. D. Whitney LGL 222, Sapir L 109-).

Several authors have stressed the fact that there is no essential difference between nominal derivational suffixes and case suffixes, but that they are intimately connected. $K$. B. Wiklund, e.g. says: "Zwischen Derivationsendungen und Kasusendungen besteht aber kein principieller Unterschied" (Fest. Qvigstad 335). See also e.g. K. Schriefl KSz 13 281, G. Mészöly Nyk 40327.

A. Sauvageot says about the case suffixes in Uralic and Altaic languages: "Elles n'assument, à l'origine ancune fonction syntaxique. Elles modifient seulement le sens des mots du point de vue sémantique .. . Les formes casuelles de l'ouraloaltaïque sont purement qualitatives et doivent être assimilées aux autres suffixations dérivatives qui forment des mots comparables à nos adjectifs dérivés" (EFr I 36: 5). But there seems to exist no principal difference between case suffixes in Uralic languages and, e.g. Indo-European case suffixes. Ludwig states abont the Finno-Ugric case suffixes that here in many cases is weine abschliessung gegen die nominalbildung unmöglich" (-nen 2). In Ludwig's opinion of this point there is "der tief reichende unterschied zwischen Indogermanischer und Ugrischer flexion", but that it is "nur ein ser starker unterschied des grades... und was allerdings wichtiger ein grundunterschied", and "im lanfe der sprachentwicklung auf Indo- 
germanischem sprachboden ganz ähnliches zum durchbrucht gekomen ist” (ib).

The relationship of the function of case suffixes and of derivational suffixes in the Finno-Ugric languages manifests itself especially in the phenomenon that in some of these languages case suffixes also occur as derivational suffixes. This phenomenon has been noticed especially in the Mordvin and the Permic languages. According to M. E. Evsev'ev in Erza-Mordvin the inessive and translative case suffixes of the indefinite declension also occur in the function of substantive derivational suffixes, as all definite declension case endings in the singular and plural can be added to them, eg. of the indefinite inessive form paksaso 'on the field' it is possible to form definite nominative paksasos 'that which is on the field', plural palisasotne 'those that are on the field', inessive paksasos't 'in that which is on the field', elative paksasodos't 'of that which is on the field', etc., all cases of the singular and plural; likewise of indefinitive translative kudoks 'for the house' - definitive nominative kudoksos' 'that which is for the building of the house', plural kudoksne, allative kudoksonten (-steń) (OMG 106-; see also F. J. Wiedemann MGr $\$ 25$. J. Budenz NyK 19 74, 128; J. Stelter NyK 22453,456 , D. R. Fuchs KSz 13 95; Ö. Beke KSz 1562 note, A. A. Šahmatov MÉS 782).

In Estonian, too, the inessive suffix $-s$ artually occurs as a derivational suffix, except for the difference that the word that is in the inessive case is not congruent with the principal word, in constructions like silmad on aukus 'eyes are in hollow (hollow-eyed)', kottis püksid 'trousers in bag (baggy)', mures näoga 'with face in worry (worried)', pilves ilm 'weather in cloud (cloudy), näljas inimene 'man in hunger (hungry)' etc. Cf. also Livonian suolms 'in knot (knotted)' (LGr 23), Finnish poika on nälissänsä ja janoissansa 'the boy is in his hungers and thirsts (hungry and thirsty), mies on taudissa 'the man is in illness (ill)', kivi on lujassa 'the stone is fast' (E. N. Setälä SKL 53), and Hungarian adjectives, like éhen 'hungry' (locative of éh 'hunger').

On Mordvin prolative Steuer gives the following example: 
pi̊lmanžavat panarỉnza, lener-pakaŕgat ožanza, sur-preacal suritdanza 'his shirts (reaching) to the knee, his sleeres (reaching) to the elbow. his fringes (reaching) to fingertips' ( $\mathrm{XYK} 22$ t56; cf. Budenz UA 301). Cf. also Estonian polvini luub 'a knee-long coat'. maani särl 'a shirt reaching down to the ground' (pólvini, maani are terminatives) etc. Cf. also Mongolian amidu 'living. alive' (locative from ami life) (X. Poppe Language 30575 ).

The elative suffix $-s$ of the Permic languages occurs as a real derivational suffix. That the Permic possessive derivational suffix -s was formerly an elative suffix with which it is at present phonetically exaletly identical. has been proved by Fuchs KSz 13 85-- (in detail .JSFOn 30:14 2--), where numerous instances are given. E.g. Votyak śüriśjos a ̌ä ortřoze̊, aziśjos siịä kiloze 'the last will be first and the first last' (88), Zyrian vistav astat gortisjeste 'tell to your domestics' (90). Fuchs explains the transformation of the elative case suffix into a derivational suffix by the fact that their meaning is so closely related, which he demonstrates by means of instances where it is difficult to determine whether we have to do with an elative adverb or with the derivational suffix on $-i s$ and attribute, like so göršolies makeinosiz nul uuck, gurtlis kid̆oke og śu ț̣̌sǎ̌em, kuštini luuzu die Sachen müssen aus dem Topfe in einen Abgrund ungefähr hundert Klafter rom Dorfe entfernt geworfen werden' (92) -- whether the things in the pot must be thrown' or 'the things must be thrown from the pot'? In Estonian too the elative suffix -st actually occurs as all adjective derivational suffix. with the only difference that the elative word is not congruent with the principal word in constructions like maja on kirist the house is of stone', traadist aed 'fence of wiregrating', etc. ('f. also Livonian hust 'knöchern' (Sjögren LGr 23), Finnish sormus on kullasta the ring is of gold', Vepsian hertse tohespai it is of bark, olgespai kanaine 'a hen of straw', etc. (Kettunen VLT 81-, 190). ('f. also the occurrence of the ablative case as attribute in Ostyak and Vogul in constructions like Ostyak jiba süzla lint pōsenen 'zwei handschuhe aus uhuhaut', no $\chi$-sō $\not$ tò 'aus elentierhaut', ef. Estonian podranahast kindad 'gloves of elk- 
skin'; Vogul kwot'l äyi 'mittleres mädchen', sāsèl lap 'decke aus birkenrinde' (S. Patkanow - R. Fuchs LFSO 98).

In Votyak the egressive suffix -śän (-śen) occurs in some instances as a nomen possessi suffix, e.g. korkaśänlän, gurežulisänlän nimzi odig to 'those coming from the chamber and those coming from the mountain foot have one name', ludysenlen inmyśenlen nimyz odyg 'eines auf dem Felde und eines am Himmel Befindlichen Name ist der gleiche' (to the suffix -sä̈n, -sen has been added the adessive suffix -län, -len) (Fuchs KSz 13 96-). The Zyrian adessive suffix -lön occurs in the function of a derivational suffix in the following example given by Wiedemann kesarly kesarlönsö, jenly jenlönsö setö 'gebet dem Kaiser das dem Kaiser Gehörige und Gott das Gott gehörende' (SGr 113) - to the adessive suffix -lön here has been added the accusative suffix -sö of possessive declension.

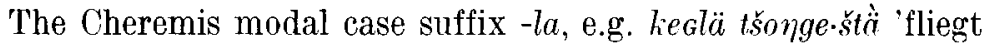
wie ein vogel', occurs also in the function of an adjective suffix, e.g. rušla-türə̀ 'ruschisches muster' (Y. Wichmann JSFOu 30: 6 18).

The same phenomenon also occurs in other language families. It is especially striking in Altaic languages where it is present in all language groups, and is known as slouble declension". E.g. the Turkish ablative suffix -din and the instrumental suffix -in also occur as derivational suffixes (A. Gabain $\mathrm{ATG}_{\mathrm{T}}$ $88-, 150-)$. According to Ramstedt in Turkish occur the dative $-\gamma a+$ the lative $-r u$, e.g. gayanyaru 'zum kaiser hin' (E II 38). In Chuvash e.g. according to J. Benzing the adverbial case suffix may be added to every dative, e.g. the dative $k i l-\varepsilon$ 'dem hause, zum hause', thereof the adverbial kilkll $\varepsilon$ 'zum hause hin'; in the same way the ablative + instrumental may be added to every noun, e.g. mal-ban-Ba 'von anfang an bis jetzt' (see further ZDMG $96451-$ ). In Mongolian there occurs e.g. dative-locative + ablative, e.g. (Khalka) gertēs 'aus dem hause' (gerte 'im hause' is locative of the word ger; $-\bar{e} s$ is ablative suffix) (O. Pritsak UAJb 24: 1-2 62, see also Poppe GWM 77, KMG 68, Language 30 576--). In Tungus, words equipped with comitative suffixes -nun and -tai, if preceding as attribute a substantive in the accusative case, 
are congruent with the latter, i.e. the accusative suffix is added to the comitative suffix, e.g. kirancika-taj-wa awsa-wa amawr 'die kiste mit dem adler tragend' (-wa is accusative suffix) (K. Bouda IF 60 19). The Instrumental, too, can be formed of the comitative. Poppe says that this double declension is due to the fact that in Tungus there is no sharp difference between derivation and flexion (M 6; cf. J. Benzing UAJb 25 115). In Mongolian almost all case suffixes may be added to the comitative with the suffix -tai, which according to Poppe was originally a denominal noun with the meaning 'possessing something' (GWM 78, KMG 68).

In Caucasian languages the Abkaz directive case suffix $-x i$, $-x^{\prime}$. the Ubykh and Circassian comitative suffix -la, -lä, resp. -ra, -re. as well as the Ubykh local and instrumental case suffix $-k \dot{a}$ also occur as derivational suffixes (G. Dumezil IfC 66,67 , note 1 ). In the Melanesian Jabêm language the locative suffix -iaa, which has sereral meanings, also occurs in the function of an adjective derivational suffix, e.g. undamb $\hat{e}$ 'heaven', undambêna 'towards heaven, heavenly' (O. Dempwolff (rrJ 26, 38, 48, 60, 76). In the same language the comitative preposition to (e.c. dec to bu kêsa 'blood together with witer came out) has in some instances agglutinated with the principal word. forming adjectives, e.g. towae with fame $=$ famous' (ib. $26-.46-.76)$. ('f. also Finno-Ugric comitatives, such as Estonian sabaga täht 'star with a tail (comet)', Lironian mümaks liala 'rogner" (LGr 260): Vepsan netse ak ratsajke that woman is pregnant (with a stomach)' (Kettunen VLT 81): Ostyak üdat roš heldenstadt", turat rat 'ein mit morschem holze bestreuter ort' (Patkanow-Fuchs LFSO 98); in Ket (Yenissei-Ostyak) according to M. A. Castrén the prosecutive suffix -hes and caritive suffix -fan also occur as adjective suffixes (JOKS 26).

In the American Klamath language the accusative-dative (objective) suffix -ash also occurs as a noun derivational suffix (A. S. Gatschet KI 323), the partitive suffix -ti also occurs as a nominal and verbal derivational suffix (374-), the locative-instructive case suffix -tka also occurs as a verbal derivational suffix $(476,376)$; the locative suffix $-n a$ and the 
inessive suffix $-i$ occur also as verbal and nominal derivational suffixes. Without knowing the history of the language it is impossible to state which function is primary, that of the derivational suffix or that of the case suffix. Likewise it is impossible to know whether we in all such instances are at all concerned with identical suffixes.

Transformation of the derivational suffix into the flexional suffir.

Flexional Suffixes of the Terb.

There are numerous instances of the transformation of derivational suffixes into flexional suffixes. This process is especially striking with regard to the verb. Thus it is known that Finno-Ugric (FU) tense morphemes are former derivational suffixes (see Setälä TuM 173; Szinnyei FUS 119-; Klemm FUF 17 265; Gy. Laziczius MNy 29 18-; J. Györke WU 90-, IIEK 95-). E.c. the FU present tense morpheme *-k- (e.g. in Estonian impersonal saadake "is obtained") is in all probability identical with the same deverbal noun derivational suffix, which occurs e.r. in Estonian pilge $<{ }^{*}-\rho k$ "mockery". The preterite morpheme ${ }^{*}-i$ - (e.g. Estonian pesi "washed') is presumedly of identical origin with the Baltic Finnic (BF) nomen agentis suffix -ja, e.g. Estonian paluja 'begger. who begs', which Ravila believes to be equal to the dererbal noun suffix $-i$ in words like Estonian laul<laulu $<-\circ<*_{-o i}$ (Vir. 1945 151; cf. L. Hakulinen SKR 1 195). Another FL preterite suffix *-s-, e.g. Ostyak mands 'er ging' is likewise a former derivational suffix. cf. (Istyak nomas 'verstand, vernuft, sinn" (FUS 123--). Several Uralic present tense morphemes are originally frequentative rerb suffixes. thus Votyak -śk-, Vogul -nt- (Horger MIT 95, Györke XyK à 93--, K. Horváth ib. 130), Ostyak - $d-\sim-t-($ LFSO 176), Samoyedic -mbi-, $-b i-\sim-p i-$, -ta-(Györke XyK 51 62). According to Szinnyei (XyK 112) the Hungarian future morpheme -and-, -end- was originally a frequentative verb suffix, and according to S. Simonyi and Horger (MIT 97) the verb suffix -amod-, -emod-, which occurs 
e.g. in the verb futamodik 'to run away'. In Samoyedic the inchoative verb suffixes $-g u^{-} \sim-k u^{-},-d \bar{a}-\sim-t \bar{a}-$ occur as future morphemes (Gÿrke SyK 51 95-).

In Indo-European languages e.g. the aorist morpheme -sis equal to the derivational element $-s-$. The Armenian aorist $-c$ - is the former Indo-European verbal derivational suffix -ske-. The Greek aorist suffix - $\theta \eta v$ - has been explained by the IndoEuropean derivational element $-d h$ - (cf. e.g. W. P. Lehmann Lg 19 22-). The Greek perfect $-k$ - is according to Lehmann a derivational element (ib.), which also occurs in nominal forms. As regards other language families, e.g. the Dravidian future morphemes $-k-$ and $-p$ - are according to J. Bloch identical with derivational noun suffixes, $-k$ - also being a dative morpheme and $-p$ - a causative verb morpheme. It is interesting to notice that the preterite morphemes, -t-, -in-, -an- also are oblique case morphemes (SGI,D 60). It may be assumed that the latter were formerly derivational suffixes.

All FU modal morphemes were also formerly derivational suffixes (Setälä TuM 166-). The imperative morpheme ${ }^{*}-k$ (e.g. Estonian pese $<{ }^{*}$ pesel 'wash') is the same derivational suffix as occurs as morpheme of the present tense (FUS 126). The BF potential (FU conjunctive) morpheme -ne-, e.g. Finnish saanen 'perhaps I get, receive'. is probably the same verbal suffix as occurs, e.g. in Estonian pogenema "to flee" (FUS 125). The Estonian conditional morpheme -ksi- $\left(<^{*}-i j k_{\text {śs }}\right.$-) and Fin-

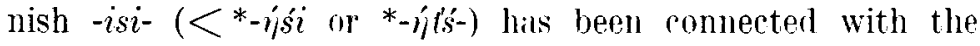
derivational suffix which occurs, e.g. in Estonian racisema to take care of, cure". Finnish valaisen, calaitsen "I shed light upon' (Hakulinen SKR I 218--). Ravila has comnected it with the noun suffix -itse-, -ise- which occurs, e.g. in Estonian päitsed 'bridle', naise 'woman (gen.)' (FUF 23 56-9).

In the sphere of the Altaic langllages, according to Ramstedt. the Turkish conditional morpheme -sa-, se-, for example, is a former denominal derivational verb suffix (FUF 29 120--).

The BF passive morpheme $-t(a)$ - is probably identical with the causative verb suffix -ta- which occurs e.g. in Estonian tõstan 'I lift, raise' (T. Lehtisalo PUA 328, Hakulinen SKR I 214-). It has been assumed that the Hungarian passive 
morphene -1 is of the same origin (cf. Simonyi JSFOu $23: 12$ 2--, Szinnyei NyK 78; divergent opinion, Klemm MEK 186-). In Lappish dialects, Vogul and Ostyak occur passive morphemes $*_{-} \beta$ - and $*_{-j-}$, which were originally reflexive verb suffixes ( NyH 75, Lehtisalo PUA 43-, 77, cf. Mészöly NyK 51 2-).

Likewise all morphemes of infinite forms of the verb were originally derivational suffixes, properly speaking verbal noun suffixes. E.g. the BF infinitive morpheme -ma (e.g. Estonian söma 'to eat') is the same derivational noun suffix as accurs e.g. in Estonian (surm:) genl. surma 'death', sööma (aeg) 'eattime, meal' (FUS 81). The t-element which occurs in BF infinitive morpheme ${ }^{*_{-}}$ak (e.g. Estonian saada 'to get, become') is a verbal noun suffix, cf. Vogul naimt 'thought' (FUS 79).

Even a certain number of FU personal morphemes were originally derivational suffixes. Thus the $-b,-v a$-element in Estonian indicative present 3rd person sg. $-b$, pl. -vad, which occur as personal and not as present tense morphemes, as which they usually are treated in Fimno-Ugric linguistic literature (see e.g. FUS 121), ${ }^{1}$ was in all probability originally the same derivational suffix which in the present participle (e.g. Estonian lugev: gen. lugeva '(the one who is) reading') and e.g. in the word lihav 'fleshy, corpulent' is represented in the form $-v:-v a$. That in the ending - vad the -ra-element belongs to the personal morpheme and is no morpheme of the present tense, is also confirmed by the fact that it has also spread to the imperfect tense (e.g. in Estonian dialects tulivad. Finnish tulicat 'they came'). The same derivational element is also contained in the Lappish 1st person plural morpheme $-p,-s$,

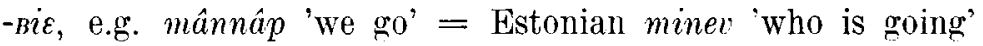
(E. Itkonen MSFOu 98 304). The origin of the Hungarian personal morphemes of the verb is especially instructive. as only a part of them were originally pronominal person morphemes, whereas the other part were originally derivational suffixes or plural morphemes (see Z. Gombocz UJb 10 4-, Horger MIT 6-). Thus the 2nd person singular morpheme

1 Cif. 1. tule-n 'I come', 2. tule-d 'you come', 3. tule-b 'he comes', plural 1. tule-me 'we come', 2. tule-te 'you come', 3. tule-vad 'they come.' 
of subjective conjugation $-s z$ is according to Szinnyei ( $\mathrm{NyH} \mathrm{64)}$ in verbs like tész 'you do', lész 'you get, become', and according to Gombocz (U.Jb 10 5) also in verbs like rórsz 'you wait', adsz 'you give', identical with the frequentative rerb suffix $-s z$ (cf. also E. Sámson MNy 49 341-). According to J. Juhász (MNy 35 284-) and E. Moór (ALH 2 81) the 2nd person ending $-l$, e.g. eszel 'you eat', is likewise identical with the frequentative verb suffix $-l$ - which occurs, e.g. in the word sujtol 'to strike'. The 1st person singular ending $-k$, e.g. vétek 'I sin', is according to G. Pais (MNy 27 143), Juhász (MNy' 35 282-) and Sámson ( $\mathrm{MNy} 47229-$ ) identical with the derivational noun suffix $-k$, cf. rétek 'the sinning', according to E. Moór (loc.c.) it is identical with the momentaneous verb suffix $-k$ - which occurred originally in inchoative function (differently Gombocz UJb 10- and Horger MIT 9-). The 3rd person morpheme $-n$ in verbs like teszen 'he does', leszen 'he becomes' was originally a deverbal noun suffix, cf. e.gr. haszon 'advantage, profit' (UJb 10 12).

The same phenomenon is also to be found in other linguistic families. Thus, according to Bloch, in Dravidian languages the Old Tamil 1st person future suffix -al (e.g. kẹt-p-al 'j'écouterai', is identical with the noun suffix which expresses action, cf. peyal 'pluie', peyardal 'changement'; Bloch is inclined to interpret the Canarese 3rd person suffix $-g u m \sim k u m$ as a substantive suffix (SGLD 43-).

\section{Plural suffixes.}

As regards the nominal flexion there are instances of the transformation of derivational suffixes into flexional suffixes especially in the sphere of plural suffixes. The BF and Lappish plural morpheme $-i$ was according to Ravila originally an adjective suffix, which occurs e.g. in compound words, such as Estonian sepikoda 'smithy', vakuraamat (<*a $<$ k̆koi-) 'district-book', Finnish karjoi-piha 'cattleyard', aitoi-vieri 'fence side', and which is probably identical with the diminutive suffix -i (FUF 23 52-; 27 86-; cf. J. Mägiste CLSE 30 460-. 
EK 1933 125-, B. Wickman FOLL 148). This FU adjective and diminutive derirational suffix $-i$ was connected with the plural morpheme $-i$ by T. (i. Aminoff as early as 1871 (Suomi II: 9 260). O. Grotenfelt was of the opinion (1876) that the derivational suffix $-i$ originates from the plural $-i$ (Suomi II: 12 358). Farkas also derives from the same (possessive adjective) derivational suffix the plural morpheme $-i$ - which occurs in Hungarian possessive suffixes, e.g. kezeim 'my hands ( $\mathrm{C}^{\circ} \mathrm{AJb} 25$ 52-). According to Bubrih the plural morpheme $-i$ may be comnected with the $\mathrm{BF}$ local and collective derivational suffix $-j a,-j a ̈$ which occurs e.g. in Finnish liaikiti(j)alla everywhere' (('ESE 30104 , JaM $11 \quad \bar{i}, 79$; as regards the suffix -ja, -jä see E. A. Tunkelo Vir. 1932 389--; 1933 9-; MSFOn 67 385-; cf. Uotila Nỵ 50 468, 473, X. Ikola F(YF 29 155). Y. H. Toivonen alludes to the possibility that the derivational suffix contained in the plural morpheme $-i$ may in the beginning have had a local meaning and that the adjective suffix $-i$ and the suffix $-j a,-j a ̈$ are one and the same derivational suffix. As a matter of fact Toivonen connects the suffix $-i a$, $-i i a$ with the FU lative suffix $-i$, the "xistence of which he assumes in BF particles like Estonian läbi 'through'. Finnish auli 'open', halki 'through', etc. (FUF 28 9--, $1 t^{-}-$-). Toironen mises the cluestion whether this lative - $i$ might not be identical with the adjective suffix and plural morpheme $-i$ (ib. $18--$ ). According to Uotila the local suffix $-i .-i$ with which Uotila also comnects the Lappish plural genitive and instructive and $i$-diminutives, was formerly an adjective derivational suffix (Vir. 1945 129--). ('oncerning the occurrence of the same suffix $-i,-i$ as coaffix in several Permic cases, see Uotila Vir. 1945 330--.

The plural suffix of the predicative adjectives which occurs in Permic languages, Zyrian - $s s$, Votyak -eś, e.g. Votyak soos uzyres "they are wealthy", was originally a possessive adjective suffix which occurs e.g. in genes 'harig' (Ravila FUF 27 100).

Still other FU plural morphemes have been connected with the derivational suffixes which originally denoted locality if $^{\circ}$ the notion of collectivity connected with it. According to Ravila (FCF 27 68) it is possible that the Hungarian plural 
morpheme $-k$, e.g. hizak 'houses', is the same collective suffix -kk which occurs in Estonian, e.g. in kuusik 'spruce forest', lepik 'alder-tree forest' (see Lehtisalo PUA 360), and the collective meaning of which has developer from the notion of locality (cf. Hakulinen SKR I 136, cf. also Bubrih CLSE 30103 , JaM 11 78, 80). Farkas has arrived at the same result (CAJb 24: 3-4 53-). The Ostyak-Samoyede plural suffix -la, e.g. logala "foxes", is according to Lehtisalo identical with the Cheremis collective derivational suffix -la (PUA 151), but concerning the latter it must also be taken into account that it may be identical with the Tungus plural suffix -l (see D. Sinor AM $2214-$-). The l-element in the East Finnish and Carelian phural suffix -loi, -löi (e.g. taloloissa in houses) was according to A. Ahlq̨rist a diminutive suffix (SKR $87-\cdots)$. Y. Wichmann (JSFOu 30: 6 17) raised the question that it might be connected with the (heremis collective suffix -la (cf. also Lehtisilo PCA 150) whereas Bubrih comected it with the BF collective and locill suffix -la ((LSE 30104 note).

The transformation of original local and collective suffixes into plural morphemes also occurs in other lingruistic families, e.r. Armenian -stan (J. Karst GrKA 196-, ef. Royen XKs 471, 649--). Basque -eta (H. Gavel GrB I (halp. II 54). As regards the transformation of collective suffixes into plural suffixes, there are numerous instances from various language families. E.g. of the Altaic languages Turkish -lar etc. (see further Pritsak CA.J1) 24: 1 67--. 84-); of Indo-European linguages, e.g. Middle Armenian - ni, -di, -ri -ier, -an, -stan (Royen NKN 641), Indo-European neutral plural - $\bar{l}$ (ib. 596--, (604-- ), likewise in Polish (629-...) and in Celtic (633-); further e.g. in Semitic languages (the so-called plurales fracti) (605-), in Sudanic Bari (607) and Massai (608), in Polynesian languages (609). A semantical parallel is the fact that the plural is expressed analytically by means of a noun or a particle which has collective meaning. This phenomenon occurs especially in the Far East languages, e.g. Tibetan expresses the plural with the particles mams, dag, cho, etc., the original meaning of which is 'groupe, piece, ensemblage'; the same applies to ('hinese, Japanese (C. Regamey ASt $1 / 260)$ and Malayo-Poly- 
nesian languages. A great number of such words that denote the plural have subsequently agglutinated with the principal word, and have thus been transformed into plural suffixes.

\section{Comparison suffixes.}

Comparison suffixes, too, are often former derivational suffixes. Thus the comparative and superlative m-element which occurs in some FU languages is identical with the denominal suffix $-m(a)$ which is present in e.g. Finnish word rantama 'coast' and in the Estonian pronoun tema 'he, she' (Ravila FCF $2441-$ ); the $p$-element which is added to $m$ is probably identical with the derivational suffix which occurs in adjectives like lihav 'fleshy, corpulent' (ib. 48-). The Votyak comparative suffixes -gem and -ges are also derivational suffixes (Fuchs FUF 30165 ; on the nccurrence of Vogul derivational suffixes $-\eta$ and $-\chi$ as comparative suffixes, see ib. 156, and on Samoyedic. Castrén SamGr 189).

\section{Genitive and Locative.}

There are relatively fewer positive instances of the origin of case suffixes from the derivational suffixes than concerning such genesis of other flexional suffixes. The FU genitive suffix $-n$ is generally assumed to be a former adjective suffix (see e.g. Wiedemann MGr 21, Budenz NyK 20439 , Setälä ÄH 382, Szinnyei FUS 61, Beke Nyr 54 108-, Bj. Collinder UUA 1940: 8 41-. Farkas UAJb 25 67). This subject has been treated with particular thoroughness by Ravila FUF 27 (see esp. 75-). This assumption is sustained by the fact that in Mordvin and Cheremis adjectives occur with exactly the same suffix as that of the genitive, e.g. Mordvin ošon 'town-, of the town', Cheremis pun 'of wood' (see further Ravila FUF 27 75-).

Also in a series of other languages the genitive suffix has been connected with the adjective suffix. It is especially 
noteworthy that in the Yukaghir and in the Chukchee language group the suffix $-n$ also forms adjectives as well as genitives (J. Ankeria LUA 1951: 9 115--). In Altaic languages the Tungus genitive suffix -ngi (-ni) is composed of the ancient genitive $-n+$ adjective suffix $-k i$ (A. Salonen JSFOu $49: 3$ 12 note 2). The Turkish genitive suffix -nyny was, according to Grönbech, formerly a derivational suffix which formed possessive substantives, haring more or less the same meaning as the Modern Mongolian genitive suffix $-\bar{a}$ (Ts 106--). Concerning the $i$-cise of the Indo-European $o$-stems. which was formerly an adjective, see Ravila op.c. 81 . as to the adjective genitive of the Indo-Iranian languages, see Royen NKS $769-$ The Basque attributive genitive suffix -ko is actually an adjective suffix (( morpheme $-i$ has in C. Brockelmann's opinion dereloped from an adjective suffix of the same element ( $\mathrm{ir}$ I 460 ). In Somali the adjective suffix $-i$ is used to express the function of the genitive (Meinhof Scr. Tromb. 84). The genitive suffixes -in and -am of the Draridian languages likewise occur as adjective suffixes (Caldwell GrD 293-). Bloch is of the opinion that the Dravidian Brahui genitive suffix $-n \bar{a}$ is probably derived from the suffix -un which occurs as an adjective suffix. This -mi genitive itself may also oceur as a substantive, and new flexional suffixes may be added to it (SGLD 14-). In Australian Kabi language adjectives are formed from substantives by means of pronominal genitive suffixes (A. P. Elkin Oc. $8 \quad 15 \vec{\imath}--$; as regards relationship between genitive and adjective suffixes in other languages. see also, e.g. Royen XKS i71. L. H. Gray FI, 197-; cf. also Caldwell (irD 288).

Wiklund considered the genitive $-n$ to be equal to the instructive $-n$, assuming that both may be traced back to originally one and the same connective case (Fest. Qvigstad. see esp. 334-, 336-). Ravila (FUF 27 79-) and Collinder (SSUF 1946-48 13) agree with this opinion. Ravila also calls attention to the fact that in all Cralic languages the instructive coincides in form with the genitive, and that the functions of these cases may also be linked together. In spite 13 - Finnisch-ugrische Forschungen 
of this Ravila thinks that the genitive suffix is a former adjective suffix. Ravila calls attention to the fact that the difference between the genitive as an adnominal and the instructive as adverbial case disappears if we keep in mind that primarily there was also no difference between the noun and the verb.

The assumption that the Iralic genitive and instructive were identical in the beginning. is supported by the circumstance that similar phenomena also accur in other language families. In Altaic languages, e.g. the instructive $-n,-i n$ is often phonically identical with the genitive, and Ramstedt thinks it possible that these two cases belong to each other etymologically (E II 43). According to Bloch the Dravidian casc coaffix and instrumental case suffix $-i n$ is really an oblique case suffix marquant la relation adnominale donnant all mot la valeur d'un génitif» (SGLD 12). The Tibetan genitive and instrumental, too, are probably of common origin, as their morphemes are very much alike (genitive: -kyi, -gyi, $-y i$, , $-i$, instrumental: -kyis, -gyjis, -gis. -'is), and they in fact have also been intermingled in some texts. In this connection J. Bacot calls attention to instances where these two cases cover each other also in French: aime de Dieu par Dieu, frapper de lépée $\sim$ par lépée. loeurre dun tel $\sim$ par un tel (GTL 26).

Ravila considers it possible that the plural morpheme $-n$ which occurs in possessive suffixes is also primarily identical with the grenitive and instructive $-n$. e.g. in Mordvin ('sorazo 'his son':) t'soranzo 'his sons' (FLF 27 87--).

Several authors have, on the other hand, connected the $\mathrm{FU}$ instructive with the locative. in which case the genitive would also be identical with the locative. Ravila does not think that the instructive might be connected with the locative, because these cases differ phonically until Samoyedic (op.c. 80). However. taking into account the relationship between the functions of these cases as well as their common $n$-element. the primary identity of the instructive and locative may be considered quite possible. The opinion that the instructive has developed from the locative 
has been expressed e.g̣. by Budenz (UA 378), B. Munkácsi (BA 292), Fuchs (see e.g. KSz 7 116, FUF 18 210), Beke ( $5 y$ y 557 ), Kettunen ( $1 \mathrm{~W} \S 75$ ), Beronka (LK 74$)$. Fuchs also calls attention to the phenomenon that in several $\mathrm{FC}^{*}$ languages the local suffixes have acyuired instrumental function, thus Hordvin inessive. Hungarian inessive and superessive, whereas the Votyak inessive and instrumental are considered to be identical by Fuchs as well as Beke (KSz 7 $116-$. NyK 36 210). As regards the occurrence of Ostyak ma-locative in instrumental and comitative functions, see F. Kara $\mathrm{XyK}+133-$, Steinitz OGr 51.

Regarding other languages I). Sinor e.g. thinks that the old Turkish case suffix $-n$ which is usually called the instrumental, and which occurs in instrumental, temporal. local and modal functions, has orixinally been a local case (TP 37 138). The same is assumed by H. Hirt about the Indo-European instrumental (IG VI 58, HIs 59), and by caldwell about the Telugu instrumental (GrD $275--)$.

Sume authors have connected the FL genitive - $n$ directly, without the intermediary link of the instructive, with the n-element of the locative suffix -na. Already Boller (SKAW $1853972-)$ traced back all FL n-cases, genitive, instructive, locative. Estonian terminative $-m i \quad\left(<^{*}-n n i k\right)$ and Finnish comitative $-(i)$ ne, e.g. (mies) raimoine '(man) with wife', to me 'ase, viz. locative. The same standpoint was adopted hy. Weske in 1873 (VGFs 38-). Of the older scientists H. Winkler (CYS $208--$ ) and II. Szilasi ( SyT 1 15-) also held the opinion that the $\mathrm{FI}^{\circ}$ genitive is identical with the locative. Kettunen too is of the opinion that Veske assumption is possible $(\mathrm{LW} \$ 5 \mathrm{~T})$, basing his standpoint especially on the Livonian dative, e.tr. m'mman to me is. i.e. I have'. This 'ase is in Livonian phonetically identical with the locative rase and corresponds to the Finnish so-called dative-genitive. '.g. minun on nällia to me is hunger, i.e. I am hungry', which according to Kettunen is certainly identical with the locative, and which szinnyei traces back to the Finnic-Permic lative $*-n$, ef. Lappish $-\dot{n},-n$, Yotyak $-n,-n$, Cheremis $-n$ (pelen towards") (FLS 62, (f. also Hakulinen SKR I 87). C'heremis 
and Mordvin use the construction genitive + to be" to express the notion of have', whereas other $\mathrm{Ft}$ linguages which lack the verb "to have" use for denoting it a local case (see below 198) or dative (like Hungarian). The grenitive is also used to express 'to have' in Samoyedic and Turkic languages (see further Beke JSFon 30: 11 4-). Míszöly (MNy 23 152) and Bubrih (JM $1182-$ ) too are of the opinion that the $n$-genitive is a former locative.

Toivonen is of the opinion that it is possible in principle to connect the $n$-element which occurs in adjective. genitive. litive and possessive suffixes (FLF 28 18). Qvigstad (ASSF 12 141-), Beke (Nyr jō 4i), Kettunen (LW § 75 ), Hakulinen (SKR I 9.3) and Bubrih (JaM 11 84--) think that the locative and Finnish comitative $n$ are identical. Several anthors held the opinion that the Finnish comitative is identical with instructive. thus Ahlqvist (SKR 114-), Setälä ( $\ddot{A H ~ 380) . ~}$ A. Kannisto (TS +1230 ). Beke ( Nyr 55 47). Beronka (LK 75一). J. Mark does not consider it possible to connect the Finnish comitative and instructive (PS 228--). Ravila (FUF 27 45) thinks that the Finnish comitative was originally an adjective, thus mies raimoine might have originally meant something like "der Mamn als mit einer Frau versehener". In this case the $i$-element might be the same adjective suffix from which, as it has been assumed. the plural morpheme $-i$ has evolved. Ravila does not consider it necessary to connect -ne with the locative -na. Ravila thinks it possible that -ne is a nomen possessoris suffix. but does not consider it particularly likely, leaving open the problem of the origin of -ne. Ravila points out parallel phenomena from Vogul and Zyrian to the development of the Finnish comitative from the possessive adjective. In Vogul the nomen possessoris suffix -ris has developed into

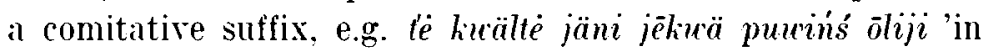
this house lives an old woman with (her) son'. In Zyrian the nomen possessoris suffix - $a$ occurs as comitative, e.g. in the sentence sili panid loi kupets's tevar-dodd'a 'ihm entgegen kam ein Kaufmann mit einer Fuhre' (or rather 'ein Kaufmann als mit einem Warenschlitten versehener') (op.c. 44). The $n$-element of the BF terminative suffix may in all probability 
also be commected with the locative $n$ (cf. also O). Dommer GV $5 \pi$. Collinder UUA 1940: 8 35).

The assumption that the Fl genitive may have originally been a locative, is sustained by the circumstance thil the identity of these cases has also been stated or assumed in nther languages. Thus according to G. Dumizil the genitive of the North Caucasian Andi language uriginates from the locative (IGC 75, 80). Dumézil thinks that the Basque (determinative or possessive) genitive suffix -en and the locative (inessive) suffix $-n$ are also identical (ib. 12(i), which riew is also shared by G. Lacombe (Comf. 5 16; concerning these ratses see (ravel GrB I (h. II 16. 27). According to Caldwell the renitive suffixes -attu, -aftru-, -ti, -in, -ni, -na of the Dravidian languages have originally been locatives, the three last occur even at present as locative suffixes (GrD 262, 287-, 305). Caldwell shows that sometimes there is but little difference between the locative, genitive and adjective. Thus e.g. the Tamil expression kulatu mîn (kulam 'tank', mîn 'fish') can be translated adjectively ('tank fish'), genitively ('the fish of the tank') or locatively (the fish in the tank") (ib. 288). The Sudanic Ewe genitive particle $\int \dot{e}$ is identical with the element -fé which denotes locality and which also occurs in the substantive $a-f r$ 'wohnort, heim' (D). Westermamn WE 17 -). According to A.S. Gatschet in American Klamath language the genitive suffix -lam was originally a locative suffix and is related with the derivational suffixes -rila and -lamna ( KT $474^{-}-$). It is also noteworthy that in the IndoEuropean Ossetian language the substantive cases inessive and genitive have on' and the same suffix -2 (H. Vogt $\mathrm{AL}$ $++1)$.

It might also be noticed that according to Trombetti all ases, except nominative, originate from locatives (EG 671 ; (f. also ib. 673 concerning the identifying of the genitive and lorative $-i$ which occur in rarious languages). Concerning the genitive relation Trombetti says that primarily it was often nothing else but suna semplice relazione di vicinanza nello spazio, ciò̀ per mezzo di forme di locatiron. Trombetti quotes as an example from the Mundari language en hatu-re in this 
village' : en hatn-re-n houn-lio people in this village = people of this village", which he compares inter alia with Russian y.нен. книга "with me is book = I have a book" (EG $267_{-}$). Here conld be added e.g. Roumanian dialectal la mine este 'bei mir ist' which has the same meaning (E. Seidel BL 13 77). Similar expressions for 'to have' also occur in other languages. e.g. in the Altaic language family in Yakut, Mongolian and Tungus, in the Hamitic Temashek, in several Caucasian languages, in Burman, Tibetan and Yukaghir (Winkler UVS 208). From the $\mathrm{FL}$ languages one might compare Estonian mul on raamat 'I have a book', where a local case (adessive) also occurs. The same phenomenon is present in Permic languages where. moreover, the adessive also occurs in genitive function, e.g. Totyak niugizlen kiiaz zarni zundesez rịuem an der hand des mädchen war ein goldener ring". ('f. also Estonian naime tal on haige as well as Russian жена у него бо.ıьн 'his wife is ill. In Lappish dialects too, the inessive is used to express to have (ef. further Beke JSFOl 30:11 1 -). As a comparison it may also be mentioned that according to Dumézil all cases in the so-called a-group of the North-eastern Caucasian languages originate from local suffixes (IGC 80).

It is evident from the above that the origin of renitive from locative function is also possible as regards the FC genitive. If we on the one hand assume that the genitive suffix was originally an derivational adjective suffix, and on the other hand a locative case suffix, then it has to be assumed that the function of the derivational suffix is older. The question arises: was the original meaning of this derivational suffix general and abstract (more or less as the present Estonian adjective suffix -line) or concrete and local, signifying something like 'being in something'? This question is difficult to answer, and it is connected with the problem of the meaning of other derivational suffixes, which will be treated below. Hakulinen thinks it possible that the pronominal suffix -na in Estonian words mina. 'I', sina 'you' is identical with the denominal suffix -na (Lehtisalo PUA 119-), e.r. in Estonian räpen : gen. räpna vent-hole for smoke'. Hakulinen maintains that in such a case mina might have originally signified some- 
thing like 'I here' and sina 'thou here' (SKR I io, note). Thus Hakulinen ascribes to the suffix -na a local meaning. Munkácsi had already earlier expressed the opinion that the $n$-element of pronouns is probably a demonstrative pronoun (or rather deictic particle), which might be compared with constructions like the German ich $d a$, du dort, Latin tu iste. In TavgySamoyede forms man-nañ 'I', tan-nañ 'thou' nañ also probably is an abbreviated form of the demonstrative pronoun naman (BA 252). The local meaning of the pronominal $-n$ suffix also seems to be alluded to by words in other Uralic languages which are equipped with this suffix, e.g. Mordvin tona 'jener', Tavgy-Samoyede namanie 'dieser da', Yenissei-Samoyede inō 'dieser da' (Lehtisalo PUA 388--, Ojansuu AUFA B 1: $326-$-). It is probable that this pronominal suffix $-n(a)$ had originally a local meaning as demonstrative pronouns are usually connected with the notion of locality (cf. e.g. on the languages of primitive peoples, (zermak, Fest. Meinhof 206-). If the pronominal suffix $-n a$ is identical with the denominal $-n a$, then the original meaning of the denominal -na may also have been local. From this derivational suffix denoting locality, on the one hand adjective suffix, and on the other locative and genitive cases, as well as instructive and other cases with the $n$-element, may have originated. Bubrih also thinks that the locative $-n$ is identical with the derivational suffix $-n$ and has evolved from the local meaning of the latter (JaM 11 $70-, 84-$; UZ $264-$ ). Sinor is of the opinion that the local suffix is identical with the $\mathrm{FU}$ deverbal nominal suffix $-n(a)$, e.g. in Estonian kohin (gen. -na) sough (TP 37 151), which may probably be connected with the denominal suffix $-n(a)$ (Hakulinen SKR I 172).

Ravila, mentioning the question of the "glottogonic" origin ofi the $n$-genitive, points to a possible explanation according to which the genitive $-n$ was originally a sentence-phonetic "hatusfüllendess element, similar to other phenomena of the same kind which occur in the present day Altaic and Uralic languages. Ravila refers to Yukaghir in which, according to Jochelson, it is not completely clear even at present whether $n$ is a genitive suffix or a sentence phonetic element (FUF 27 
$84-)$. This possibility of explanation ought to be taken into account, though it cannot be considered convincing.

Other Cases.

Bubrih is of the opinion that the FU lative suffix $-k$ is derived from the derivational suffix $-l_{a} \sim{ }_{{ }_{k}} a$ which is added to pronominal stems, and which originally denoted place, e.g. in Finnish siell $\ddot{a}<{ }^{*}$ si $_{k} \ddot{a}$ llä 'there', Finnish muxkalainen 'stranger' (CLSE $3010 t$ note, JaM 11 85-, 82). According to Setälä this derivational suffix $-7 a \sim-_{k} a$ is identical with the Samoyedic coaffix -ha-, -ga-, -la- which occurs in the Samoyedic locative suffix -kana and the ablative suffix -hata, e.g. YurakSamoyede locative jindakana 'soul'. Tavgy-Samoyede ablative jamkata 'sea' (JSFOu 30: 5 23), and which O. Donner connected with the Mordvin prolative suffix -ka, -ga, -ra (MSFOu $¥ 160$ ). The latter was connected with the FU lative suffix $-k$ already by Budenz (UA 378). According to Ojansuu the pronominal -lia is probably related to the lative suffix $-k$ and with the Mordvin prolative suffix (AUFA B 1: 3 9). Collinder is also of the opinion that Setälä's and Domer's hypotheses are consistent (UAJb 24: 3-4 11-). ${ }^{1}$ Lotila (Vir. 1945 333-) also connects with the above the Permic adrerbial case suffix -ja, the a-element of which Uotila considers to be identical with -a occurring in adverbs, such as Zyrian, Votyak kuza 'along', Zyrian luna 'in the daytime' which may have been derived from the suffix -ka, as well as the Lappish suffixes containing the element $k$, in such adverbs as de $i^{\prime} k \check{e}$ 'here, to this place', $i k$ 'ko 'at night, by night'. According to Uotila these Permic, Mordvin, Lappish and Samoyedic suffixes may be related to each other, if we assume that they all originate from the ancient derivational suffix -ka which has also been

1 Collinder has connected the Samoyedic -ka- with the Yukaghir locative suffix -ge, -go, - yo which also has lative function, and the Samovedic locative suffix -kana with the Yukaghir prolative suffix -gen, -yon (< locative suffix $+-n)$ (loc.c. and $\mathcal{L} \mathrm{U} \AA$ 1940:8, 20--, $28,30-1$. 
used adverbially. The same suffix occurs, according to Uotila, in words like Zỵian Permyak dialect t'seri-gada, Finnish kajaca, Kola-Lappish liajeg. Uotila (as well as Lehtisalo) seems to connect the derivational suffix *-la occurring in these words with the BF derivational suffix $-k$ in words like Estonian leede $\left(<{ }^{*}\right.$-el $)$ 'sand-bank', since Uotila indicates the corresponding passage in Lehtisalo`s PUA (334--). According to Cotila the lative $-k$ may be connected with it. Toivonen seems to be of the opinion that the li-lative is primary, and that the derivational suffix $-k_{k} a \sim{ }_{-} a$ las originated from it, just as he thinks it possible that the derivational suffix $-j a$, which has also been connected with the plural morpheme $-i$ (see above 190) is meine gleichartige Erweiterung des $i$-Iatirs" (FLF 28 16--). It is, however, more probable that the derivational suffixes are primary, and that case suffixes have originated from them. ${ }^{1}$

According to Bubrih the ablative suffix -ta is identical with the derivational suffix $-t$ and has originated from a local meaning (.JaM 1185 ).

The Finnic-Permic abessive suffix -ttak which contains the same tt-element as occurs in the Estonian caritive adjective suffix -tu (<-*-ttoin:-ttoma-), e.g. saamatu, Finnish saamatom 'clumsy, helpless', is in all probability a former derivational suffix (cf. Wiedemann MGr 22-). The element $-k$ of the abessive suffix is a lative suffix, and the Estonian expression jaii rahata (he) was left without money' might have meant primarily something like 'became moneyless' (FUS 92; Hakulinen SKR I 91-). Cf. also the occurrence of the Estonian abessive suffix in the function of derivational suffix in constructions like sabata koer 'dog without tail, i.e. tailless dor", lamnatamata inimene 'impatient man', häbemata poiss 'impudent boy', lirjutamata livi 'unwritten letter', hoolimata inimene 'ruthless man: in Estonian dialects it even occurs that words equipped

1 According to A. Yesheim the FU lative $-k$ is identical with the g-element of the Lappish verbal derivational suffix. which occurs e.g. in verbs like bonjagit 'become twisted, crooked'. njuol gât 'become straight, remain lying' (MSFOu 98 182-). 
with abessive suffix are declined, e.g. häbematad imimesed 'impudent people', etc. (Mägiste KTT 190--).

Ravila is of the opinion that in the Mordvin adrerbs casolo 'far', iliele 'in front. ahead' there is no $\mathrm{FU}$ locative suffix -na, but that the adessive function here is fulfilled only by a derivational suffix containing the l-element. Ravila thinks that here it is a question of the development of attribute into idverbial, and that possibly also in the Finnish adessive $\left(<^{*}-\ln a\right)$ the locative $-n a$ is pleonastic (Vir. 1945 158). In connection with this Uotila has raised the question (Vir. 1945 $334-$ ) whether the l(a)-element which occurs as a coaffix in Finnic-Permic external local cases (see below 214) and which is thought $t o$ be identical with the derivational suffix -l.a a acurring e.g. in Estonian edela 'south-west', has not also occurred independetly as a case suffix. Uotila, however. has no further proof of the above than the opinion that at the end of the Lappish adverb mâmmel 'behind occurs only -la. not -lna. In connection with this Uotila calls attention to the various functions of the Ugric l-suffix (which has been considered to be a representative of the $\mathrm{FC}$ ablative *-ta), e.tr. the Hungarian ablative (alol from underneath'), the locative (alul below'), the essive and factive (rendégül as a stranger'), the modal (jót 'well'); the Vogul comitative (ampal with the $\mathrm{dog}^{\circ}$ ), the instrumental (niald with the arrow'), the modal ( $i$ üral in this way"). Uotila states rightly that it seems strange that all these meanings should derive from the ablative, and adds: if this, nevertheless, should be a question of the FU ablative suffix $\left.*_{-}-t a *^{*}-\delta a\right)$, then its varying meaninw depends on the fact that we even here are concerned with an ancient derirational suffix $\left(?=*_{-}-t a, *_{-} \delta a\right)$, cf. e.g. Finnish ralkea 'white; light', Lappish rielgad, Mordvin raldo, caldă, etc. (c.f. MSFOu $6594-5$ ). Finally Uotila raises the question whether the derivational suffix -la. with which E. Iooir later on has connected the Hungarian case suffix -l ( Ayr 70127 ), should not be taken into account here too.

Ahlyvist connected the BF translative suffix $-k$ si $\left(<{ }^{*}\right.$-kse $)$ with the derivational suffix -kse in words like Finnish terras 'tiury tree', aidas 'fence-pole', Estonian remnaksed 'brothers, 
brethren', South Estonian katuke 'roof, gen.: thinking that the function of the rase suffix was primary (SKR 109). (1. Donner is also of the opinion that these suffixes belongr to each other ( $\mathrm{HV} 83)$. A. (ienetz on the contrary thinks that the function of the derivational suffix is primary (SP 168). Jotila also thinks that tienet $\%$ opinion is wery seductiven (Vir. 1945 336). The general view is that the translative suffix -hise consists of two lative suffixes (see below 206).

J. Krohn in 1872. (Wiron kiplioppi. 162--). (ienetz (SP $159)$ and Ludwig (-nen th) in 1884 , comnected the $\mathrm{BF}$ prolative suffix -tse $(-t s i)<-* i t s e l\left(<*^{*}\right.$-t't'seh), e.g. Estonian meritse 'by sea', käsitsi 'with hamr. by hand. Finnish glitse over' (see Toivonen FLF 19 16t. Hakulinen SKR I 93-). with the derivational suffix -tse in words like Estonian päitsed, suitsed 'bridle', Estonian dialectal soolatsed salty'. which is the same suffix as (i)se- in adjectives like Estonian maised earthy", punased 'red, pl.' (Hakulinen SKR I 106-). Arcording to setälä there is no dombt that the Estonian prolitive forms are connected with the -tse. -se noms ( $\ddot{\mathrm{AH}}$ 189).

As we see, a great number of $\mathrm{FU}$ case suffixes have been traced back to derivational suffices.

In studying the evolution of case suffixes from lexical elements it is most instructive to observe how case relations are expressed in those African linguages which lack the case category. An interesting survey has been given by Meinhof. Scritti Tromb. 71 -. In the Bintu lanquages. for example, the functions of cases are fulfilled. besides other means used for it, by class prefixes which to their essence are lexical elements and have more or less the sime function as derivational suffixes. Yeinhof writes: "Durch eine der drei Lokatirpräfixe mu-. pa-. lik- wird ein beliebiges Jomen zur ortsbezeichnung umgrewindelt, z.B. Konde $n$-nymba $\left(<{ }^{*}\right.$ munyumba), pa-nyumba. kn-nyumba. Wenn wir diese nenen Worte in europäischen sprachen auch nit Präpositionen übersetzen. also "in dem Hause'. 'bei dem Hause. 'nach dem Hause (rom dem Hause), so sind die Vorsilben für die Bantu keineswegs. Präpositionen. sondern Präfixe. die mit den ührigen Bantuprïfixen durchaus gleich behandelt werden. Jie Worte kïnnen 
Subject und (bbjekt und Genitiv sein. sie kömnen einen Genitiv jegieren, sie bilden Demonstrative, Possessiva, Personalial. werden also välig wie andere Substantiva behandelt. Wir können sie etwa übersetzen mit 'das Hausinnere, 'die nähere Imgebung des Hauses, 'die entferntere Lmgebung des Hauses". In einer ginzen Anzahl ron Bantusprachen sind aber die Lokativpräfixe vol dem substantiv geschwunden und ersetzt durch ein suffix -int, z. B. suah. nyumbani von nyumba 'Haus', Zulu ent'a beni von int'a'ba Berg'. Diese Form sieht nun wie ein Kasus aus. ist es aber nicht. denn auch sie hann Subjekt und Objekt, Cenitiv und regierendes Nomen dem Verbum sein und nimmt die schon erwähnten Pronomina der Lokativklassen an. z.B. Suah. mbra ra meituni ist en 'Hund des Waldinneren' d.h. ein 'wilder Hund'. nymmbani pana miti genau 'die nähere Emgehmug des Hauses hat Bäume'. d.h. 'bei dem Hause sthen Bäume " 78 : cf. also Meinhof GrB 65-, E. Haddon As 10101 -). A similar phenomenom manifests itself in the class suffixes of the Papuan Nasioi language (see further Bubrih CЯ II $54 \cdots$ ). In somali occur the endings $-a,-o$ mdie wie Kasusendungen amssehen. es aber nicht sind. vie haben vielmehr lokale Funktion, wobei unterschieden wirl. ob der genannte Gegenstand dem redenden subjekt nahe $(-a)$, davon etwas entfernt $(-1$,$) inder davon weit entfernt ist (-i)$ " (Meinhof "p.c. 82--).

As an adaptation like this is going on in present day languazes there is reason for assumingr that the same process nccurred in ages long past. Since it is natural to assume that there was a time when flexion did not exist. then it may also be assumed that not only auxiliary word morphemes had in the begiming lexical function. but that once a great proportion of the flexional affixes. too. had lexical function, i.e. they were derivational affixes. It is ubrious that in languages whose history is known. the derirational affixes generally belong to an older stratum than the flexional affixes, i.e., derivation is older than flexion (cf. Trombetti EG 252, Ravila Vir. 1945150 ). It is therefore natural to assume that flexion partly originated from derivation and that some of the derivational affixes were transformed into flexional affixes. 


\section{Compound C'ase Suffires.}

An interesting phenomenon in the domain of case suffixes is formed by those instances where it has been assumed that the present case suffix consists of two case suffixes. Thus szinnyei assumed, for instance, that the first component of the Finnic-Permic illative. inessive and elative case suffixes is the lative suffix $-s$, whereas the second element in the illative is the lative suffix $-n$, in the inessive the locative suffix $-n(a)$, in the elative the ablative suffix -t(a). E.g. the Proto-Finnic illative $*_{\text {-sen }} \sim *_{\text {-hen }}\left({ }^{*}{ }^{*}\right.$-sen). the inessive -sna. the elative -sta. cf. Finnish illative taicaaseen 'into the heilven', inessive lialassa 'in the fish', elative lalasta. Lappish inessive tsailemesne in the eve. Mordvin onsne 'in dream' (FUS 66-). The ('heremis illative suffix -ške is supposed to consist of the lative suffixes $-s$ and -k, e.p. jalăška 'into the foot (FUS 68. Rilvila FUF 23 46). In Lurir languages, according ta szinnyei. a series of cases have ats their first component the local suffix $-n$ and as their second component (in the allative and the lative) the lative suffix $-z$ or $-\gamma$ (cf. Birrezi MNy 43 44-), (in the adessive and the (omitative) the locative suffix $-t$, (in the ablative) the ablative suffix -l. E.g. Hungarian dialectal allative birime to the judge . adessive bironoll at the judge. ablative bironol from the judge'; Vogul lative Bitnd 'into the Water". Ostyak comitative iminat 'with wife', Yogul ablative ampral from the dog' (FUS 65-, Nyll 131--). In BF here belongs further the pudimentary excessive suffix -nta which consists of the locative suffix $-n$ and the ablative suffix $-t a$. e.gr. Estonian loodunt 'from home", tagant from behind", Finnish dialectical takama. Intrian takiant (FUS 65). According to Mészioly the lative (ase suffix -nig which occurs in Hungarian dialects consists of two lative suffixes: $-n i<-n \dot{e}+-y<-k(\mathrm{~N} y \mathrm{~K} 40323-$ ).

Similar case suffixes occur in Samoyedic: the dative TargySamoyede -nfa, -ntar, ()styak-Samovede -nd, -ndi, Targy -tan (= -ta + lative -ı $(<-n)$, Ostyak-Samoyede -nil, -nig (=n-lative $+k$-lative): the locative Tavgy -tanu, -ntanu, Yurak-Samnyede -hana, -gana, -kana (k-lative + locative), Ostyak-Samoyede -kin, -kiit, Kamasin-Samoyede -gana: ablative 
Yurak -gade. -hada. Targy -yata. -lata, Kamisin -yatta, -ga'. -ha' (collinder LEA 1940: 8 20--. rỵirke MNy 39 190--).

$\mathrm{BF}$ and Mordvin translative suffix $*_{-h s(e)}$ is assumed to consist of the lative suffixes $-k$ and $-s(+$ vowel) (Ravilit FI:F 23 th. ef. however Vir. 1945 158: Hakulinen SKR I 88). The Hungarian comitative suffix -stul. -stül is assumed to consist of the possessive adjective suffix $-s$ - locative $-t+$ essive $-u l$ (see Ravila FIF 27 44). e.g. családostul with family'.

The transitive case suffix $-t i$ in Permic languages consists assumedly of the locative suffix $-t$ and of that local suffix $-i$ which Toivonen calls the lative suffix (see above 190); e.g. Votyak kosalti through the window' (Wichmamn FUF 16158 , Totila Vir. 1945 330).

The same phenomenon also oecurs in ot leer linguistic families. Thus in Altaic languages, the Mongrulian ablative suffix -daca $=$ the locative suffix -da - the ablative -ra (smedt-Mostaert I)M II 24). According to Ramstedt the Mongolian ablative ending - $\bar{a}$ sa, $-\bar{a} s$ consists of the old dative suffix $-a$ in locative function and of the ablative suffix -ca (E 11 33). According to sinor the Turkish ablative suffix -dan consists of the ablative $-d a+$ the locative $-n$, whereas the locative suffix $-t i n$ consists of the adverbial suffix $-t i+$ the locative $-n$. Compound suffixes are according to sinor also the locative-iblative -ta, tä, the dative $-q a$, $-k i i$, the ablative -tin and -tan (TP 37 147--; ef. Benzing ZDMG 96 t63. Gahain s(1) 14:5 10). According to K. H. Menges the ablative, Common-Turkic -dan, -dän. Ujy. - tyn. - tin < locative $-d a$, resu. -1 - instructive $-(y) n$ (Anthropos 49 1109. 1112). The phenomenon of a case suffix consisting of two case suffixes may depend un several reasons, and therefore instances from other languages families (cf. e.gr. on Basque, Gavel CrB I chap. II 2ti) cammot be used to solve the FL problems, as long as the history of these suffixes is not known.

How can the phenomenon of $\mathrm{FL}^{*}$ secondary case suffixes consisting of two primary case suffixes be explained? We may assume that at least in a certain part of these instances at the time when to one apparent case suffix another case suffix was added. the first suffix did as yet not recur as a case suffix, 
but fulfilled more or less the function of a derivational suffix, i.e. it was conceived as belonging to the word stem. Here belong in the first place the internal local cases in BF and wher languages, the first element of which is generally assumed to be the lative suffix -s. Opinions differ as to the process by which the lative $-n$, the locative $-(n) a$ and the ablative -tia) were added to this element, and it is, in fact, difficult to find an explanation for this.

According to szinnyei the illative was the first case to come into existence, i.e. to the lative suffix $-s$ another lative suffix $-n$ was added pleonastically, i.e. more or less in the same way as the addition of the Votian illative suffix $-s \bar{e} \sim-s \bar{e}$ to the allative suffix $-l \bar{e} \sim-., \bar{e}$ may be explained, e.g. si.lua.lèse on the bridge', (piäb mennä) eja.uese '(must go) to the brook',

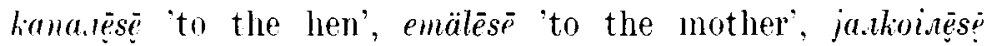
'to the feet' (Kettunen VKت̈ 75 ). Szimmyei is of the opinion that: "Sachdem man den ihm zugrunde liegenden Lativ als Stamm aluffasste, haben sich auch die beiden anderen bieder dieser "iruppe herausgebildet" (FCS 66), i.e. inessive and elative. Here it remains incomprehensible low just at a stage when the s-element was conceived as belonging to the stem, the habit could start to use it as a case element in the inessive and elative. Here is an obvious contradiction. Szinnyeis assumption is also contradicted by the circumstance that the illative is the most recent of the three internal local cases, as has been proved by Ravila. Ravila on his side presents the following explanation: if the internal local cases originate from the $s$-lative, then the "ruhecasus", i.e. the locative suffix, was the first that was added to it. Ravila adds that it is by no means an muknown phenomenon that case suffixes that have differing meanings are added to each other. However, it must be aldded here that this phenomenon in any case is in need of explanation. According to Ravila the ablative suffix, too, was subserquently added to the hative suffix $-s$, and after the origrinal meaning of the lative $-s$ had grown obscure, the second lative suffix, too, was added to it (FUF 23 46-). Ravila. nevertheless, has not explained how it was possible that the locative suffix was added to a case suffix having 
lative meaning. A contrary phenomenon might be easier to explain, i.e. if lative and ablative suffixes, which give a closer indication of direction, had been added to the general local case - locative (cf. Uotila's explanation of the external local cases. Vir. 1945335$)$.

It is obvious that at the time when the locative suffix -na and the ablative suffix -ta were added to the suffix $-s$ the latter could not have lative function, but it had either the function of a general local case or it was conceived as belonging to the stem. Since there is no foundation for the first assumption, then it is more natural to assume that at the time when the internal local cases sprang into existence, the $-s$ suffix occurred as an element of the stem, i.e. as a derivational suffix. According to Collinder the internal local cases are formed "mit Hilfe eines lokalitätshezeichnenden $s$-Formans" (CAJb 24: $3-4$ 11). ${ }^{1}$

It is also possible that at the time when those secondary local cases of which the locative suffix $-n$ is supposed to be the first component. $-n$ in them was as yet not a case suffix, but an element of the stem. As we have seen above (192--). the locative $-n$ has been connected with the same possessive adjective suffix $-n$ from which the genitive in all probability originated, and which may be identical with the substantive derivational suffix -na. The fact that in Yurak-Samoyede and Tavgy-Samoyede the plural suffix is not placed between the stem and coaffix, but between the coaffix and the case suffix $(-n a,-t a)$ seems to indicate that at the time when the Somyedic compound suffixes locative -lana, -tanu, and ablative -lana, -kata sprang into existence. the coaffixes -ka, -ta were not conceived as case suffixes but as lerivational suffixes. E.g. Yurak-Samoyede (zuda 'hand' : loc. judahana:) loc. pl. mudaha'na (cf. nom. pl. yuda'), (abl. yudahad:) abl. pl. yudaha't (Castrín SamGr 115, 125); Tavgy-Samoyede (kula 'raven': loc. kulatanu :) loc. pl. kulatinu, (abl. kulagata:) abl. pl. kulagita (ib. 159-); Yenisei-Samoyede (libe 'eilgle' : loc.libehone :) loc.pl.

1 Wiklund thought that the $s$ of the internal local cases was a determinative element (cf. I. Átányi NyK 51 350-). 
ribehine, (abl. ribehoro:) abl. pl. libehito (ib. 17t). Here it is probable that e.g. in the Yurak-Samoyede locative mudahahas been conceived as the stem to which the locative suffix -na has been added in the singular (rudahana) and in the plural the plural sion ['] + the locative suffix -na (nudaha'na), whereas in Yenisei-Samoyede Yibeho- has been conceived as the stem to which the locative suffix -ne ( $t^{\prime}$ ibehone) has been added. and in the plural the plural sign $-i+$ the locative suffix $-n a$ (libehine) (cf. Munkácsi B.A 253). According to Collinder in Common Uralic the case endings loc. *-na, abl. *-ta scould be combined only with such stems as expressed in themselves a local notion. Ordinary nouns ... could be combined with these endings only through the intermediary of a derivative suffix, as *-ka, *-kia. Tavgi kulaga- is, historically speaking. a noun stem" (SSUF 1952-54 97).

Further Inata on the Origin of the Case Suffixes.

Taking into account all the above, it may be considered probable that at least a certain part of the FU primary case suffixes were originally derivational suffixes, or that originally there was no difference between the derivational and flexional suffixes (cf. Oertel-Morris HS 16 111. 114, and above $180 \cdots$ ). ${ }^{1}$ As regards the problem as to whether the FU primary case suffixes might be etymologically connected with derivational suffixes, only assumptions are possible. Assumptions which so far lave been made concerning the genitive, locative, lative $-n$, lative $-k$ and ablative $-t a$, have already been mentioned above.

The following might be added regarding the ablative suffix $-t(a)$. Uotila has raised the question if it could not be connected with the derivational suffix $-t a \sim{ }_{t} a$, which occurs e.g. in adjectives such as Estonian pimeda 'blind' and in sub-

1 The author of the present paper came to this opinion many years ago without knowing the standpoints of Ludwig or the other representatives of the adaptation theory, not to mention the later articles by Ravila, Uotila or Bubrih. 
stantives like Estunian hobeda 'silver" (see above 202). The meaning of the latter suffix, which resembles that of a possessive adjective, fits well into the ablative function (cf. the occurrence of the elative and ablative in the function of the derirational adjective suffix above 183). Especially noteworthy also are the BF local derivational suffixes $-u s t a \sim-y$ stä and - sto $\sim-s t o ̈ ~(<$ *-sta $+i$ ), e.g. in the Fimnish words alusta 'base, basis', edusta 'front', kunsisto 'spruce forest', kalmisto 'churchyard, burial place, in which ta occurs in the function of a derivational suffix and probably is the same suffix as occurs in adjectives like Estonian pimeda (cf. Hakulinen SKR I 154--, 161).

As regards the accusative suffix $-m$, Ravila (Vir. 1945 158) has called attention to its resemblance to the corresponding derivational suffix (PCA 82--). Here in the first place the pronominal suffix $-m(a)$ ought to be noticed, which is probably identical with the corresponding nominal suffix occurring e.g. in words like Estonian tema 'he, she', nemad 'they' (PUA $386-)$. Bubrih. who is of the opinion that the m-accusative nceurred in the beginning only in pronouns, also calls attention to the m-element in FU pronouns, like Finnish tämä 'he, she', Ostyak tam 'this,, tom 'that' (JaM 1180,84 ). In many languages the accusative suffix has originated through agratutination with demonstrative pronouns (cf. Tauli UA.Jb 24: $3-4$ 28; concerning the Vogul accusative of. Limola JSF()u 57 : $125-$-). As the function of the accusative differs from that of the local cases, the accusative occupies a special position among the Ualic primary cases and may have originated in a different way than the other primary case suffixes.

The Grigin of Dericational Suffixes.

If we assume that a great part of the primary flexional suffixes were originally derivational suffixes, the question arises: what was the origin of the derivational suffixes? It has to be admitted that it is difficult to make any well-founded assumptions here. In the following we shall consider some possible explanations. To begin with there is a cardinal problem: 
aurolutination or secretion? In all probability derivitional suffixes origrinated partly in aggolutination. and partly in secretion.

As regards Ravila's pronominal hypothesis (see above 173), which is similar to Landwig's and Trombettis standpoints, it must be admitted that in principle it is quite possible. In addition to the explanations presented by Ravila, it might be mentioned. moreover. that the demonstrative pronouns, "specially in the languages of primitive peoples, are always anmerted with the notion of locality. just as well as the local adverbs are depiced fom the stems of the demonstrative pronouns. Trombetti has emphasized the important part played by deictic particles in the derclopment of language. Trombetti traces balck to deictic particles almost the whole of the flexion of nouns; viz. genus, number. pronouns, numerals and postposition. the latter hatring according to Trombetti given rise to case suffixes ( $\mathrm{E}(\mathrm{i} 284-, 748$ ). It is most probable that in the primeval stage of the language the deictic particles played an important part. ('zermak, too, says: "So geht jeder sprachliche Ausdruck auf l)emonstration zurück und darum fühlen wir in allen Demonstrationspartikeln etwas "Lrwüchsig-Primitivesm (Fest. Meinhof 206 ). (zermak also commects the personal jronouns with local conceptions (cf. the corresponding article (1) African languages op.cit. 204-). Is is possible that some of the suffixes are former pronominal stems, as has been proved uf the accusative in many languages. But there is no foundation for basing the whole of the flexion of noun on deirtic particles as Hirt and Trombetti do.

Relater with the theory of adaptation and agolutination of deictic particles is further the semantic adorghtination theory of Cuny. ('uny is of the opinion that in agres long past the so-called sempty words" which at the present time are called derivational suffixes. played in Indo-European and HamitoSemitic languages more or less the same part as the class signs in Bantu languages. Later on the original function of these classifiers was forgotten (EP 201). Bising his standpoint on Szinnyeis assertion about the FE verbal suffixes (FLS 103), in which $S z$. points to the circumstance that the different 
verbal categories are intermingled with one another, and that the meaning of many suffixes his weakened to such an extent that the meaning of the derived verb has become identical with the basic rerb. Cuny concludes that the FU derivational suffixes, too. were originally nothing but such mempty words" the main function of which was wde wignales" comme verbes (plus anciennement comme noms verbaux, noms diagents etc. ...) des dérivís qui par là sopposaient à une "racine" plus simple, semantiquement encore indivisé entre le nom et le verbe" (266. see further ib. 276). Meinhof also thinks that traces resembling the classificatory srstem characteristic of African languages can also be found in the derivation of words in African. Asiatic and European flexional languages, e.r. in the fact that nomen agentis and the abstract noun have fixed endings. Gray on the other hand is of the opinien that the Bantu class signs resemble Indo-European determinatives, i.e. derivational suffixes (FL 190. ef. also Finck Hs 46). Derivational suffixes have been compared with the Bintu class signs already by Wundt (s $\mathrm{II}^{3} 17$, cf. also ib. 18).

As the function of the derivational suffixes to a certain extent is similar to that of the class signs in the sense that both classify words (cf. further Ramstedt. JSFOu 55 103-), then they may be of similar origin. But this possibility by no means brings us nearer to a solution of the problem of the origin of the derivational suffixes, since class signs, as far as their etymology has been established. originated in several different ways. through agglutination as well as secretion and adaptation (cf. Royen NKS 780, Meinhof BGr 63-).

Beside agglutination. secretion has to be taken into consideration as a mode of genesis of derivational suffixes. A simpler subdivision of secretion which has been established in many languages in historical time, is the so-called extension of suffixes (Jespersen I,g, ch. XIX $\S 14$ ), i.e. the phenomenon that the suffix takes over some sound or some sounds from stems to which it had been added. The spreading of these extended suffixes to other words, which have no such el 'ing of the stem, proves that not the original suffix but the extended suffix is really conceived to be the 
suffix. Only in such a case can we speak of secretion. Numerous instances of suffix extensions also uccur in FU languages, especially among the derivational suffixes. A frequent phenomenon is that the rowel of the preceding stem has been added to a suffix which berins with a consonant. such derivationil suffixes extended by a rowel are, e.g. in BF ${ }^{*} e_{t} a$ (SKR I 105), -us : ukse- (122. 196), -ek (164), -ukka -iktia (e.g. in words like Estonian elukas 'beast, creature', maasikas 'strawberry') (111), -oi (150, 189), -rin : -oime (168), Finnish -isto $\sim$-istö (155), verbal suffixes -ele- (233), -oi- (248, 267), Finnish - utta $\sim-y t t a i(252)$. The consonant has been secreted from the stem and become coalesced with the suffix in e.g. the following suffixes: Finnish -sto ( $7 \bar{i})$, -tti (191), in verbal suffixes -sta- (ib.), -rta- $(267)$.

A stem ending of no less than two syllables has secreted from the instructive of the infinitive of the Finnish -ttelererbs. e.g. (ruorotella 'alternate':) vuorotellen 'alternating', and formed the suffix -tellen which has spread to words like paiko(i)tellen 'in some places, locally', yksitellen 'one by one, singly (202). See also e.g., instances from Hungarian, Simon yi TMNy $380-586$.

The same phenomenon also occurs in flexional suffixes. The rowel has secreted from the stem and coalesced with the suffix, e.g., in the following FU suffixes: Permic elative (Votyak -is, Zyrian -is. -iś), egressive (Votyak -isen) (Fuchs JSFOu 30: 147 ), inessive $(-i n)$ and instrumental (Votyak -e'n. -in, Zyrian -en) (see e.g. Fokos NyK 36 207--); the IIungarian 1st p. pl. ending -unk, -ünk (Horger MIT 11). Sometimes the original consonantal suffix has disappeared. whereas the rowel secreted from the stem alone continues to exist as a suffix. E.y. the former lative suffix ${ }^{*} k \sim{ }^{*_{-}}$has disappeared from the ending of the Permic illative, Votyak $-\varepsilon$, Zyrian $-\rho$ (Beke $\mathrm{Nyl} 5547$ ), and of the Ostyak lative $-a$ (FUS 58). Secretion of the consonant occurs in e.g. the imperfect morpheme -siin Estonian, Lironian, Votian and Finnish south-western dialects. e.r. Estonian elasin '(I) lived', in which $s$ has secreted from the contracted verbs and coalesced with the former imperfect morpheme - $i$-, e.g. Estonian magasin $\left(<^{*}\right.$ maka $\left.a_{t} i n\right)$ 
(Setialii Tull $91 \cdots$ ). The $s$ in the Hungarian comitative suffixes -stul. -stül comes from the possessive nouns, ending in -s. such as csalidos having a family', to which were added the locative suffix $-t+$ the essive suffix $-u$ (Beke Xyr 39 194--:

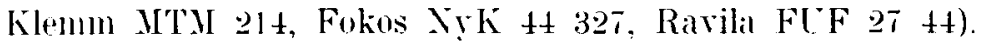
The Hungarian translative suffix $-r \dot{a},-r \dot{e}$ was formerly $-a \sim-e^{\prime}, v$ having spread to it from $r$-stems (see further Melich

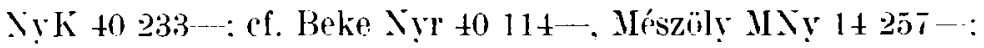
15 1.5--). According to Mészöly the Hungarian comitative suffix -ral, -rel which M[riszöly considers to be originally equal to the Togul instrumental-comitative suffix $-l$, has alsu ariminated through extension of the suffix (FLF $2156-$, for criticism see szinnyei Fl'F $2267-$ ). According to Fokos the comitative suffix -rel is identical with the gerund suffix -rel in which $r$ is the rerbal noun suffix $-r \sim-\mu(X X) 197)$. Acording to Klemm. in the Hungarian objective conjugation lst p. so. endingr -lak, -lek the l-element has secreted from the $1 \mathrm{p}$. so. verb forms of subjective conjugation like ${ }^{*}$ sujtololi: (1) strike. lierelek (I) beg' where $l$ belonged to the stem. heing a derivational rerb suffix, whereas $-k$ was the personal morpheme (MNy $21 \quad 256-$-).

Similar extension of suffix by the fimal consonant oceurs in all probability also in Finnic-Permic external local cases. in spite of Ravila's (Vir. 1945 157) and Cotilas (ib. 334-) more recent assumptions. According to the traditional view. in the Finnic-Permic allative $(-1+$ lative $-i)$. adessive $(-1+$ locative $-n-)$ and ablative $(-1+$ ablative $-t-)$ (BF *-len. *-lna, -lta, Permic -li; -len, -len; -lis, -les. the cheremis allative -lan and (?) ablative -letś) case suffixes, the l-element belonged originally to the stem, and is the same derivational suffix which occurs e.g. in words like Estonian edela southwest', Finnish setala the home of the fathers brother' (PUA $145-)$. Secretion of $l$ to lative, locative and ablative suffixes from words which denoted local relations. corresponds t" expectations, seeing that suffixes of local cases are most often adder to them (szinnyei FLS 63--. Ravila FLF 23 43--; 27 72, Hakulinen SKR I $78.90--$ : ef. Wichmann JSFOU 30: 6 15. Cutila KPs 199, NỵK 50 469: Beronka LK 219-). 
In Indo-European languitges also occur numerous instances of extension of suffixes (see instances quoted by Hirt IGr III 226--; about other langulages see Royen NKS 478).

A phenomenon related to the genesis of suffixes throurh secretion is the metanalytic renesis of words from suffixes which is the reverse of the origination of suffixes from words through agghutination. E.g. according to Fuchs the Zyrian postposition -mis (-mist) originated from the elative of verbal nouns ending in $m$ and expressing accomplished action (such as *loktemis 'nachrlem al grekommen wal", *suemiś nachdem er gesagt hatte'), the final part -mis' having been interpreted an postposition 'after' as which it has spread to expressions like lik lun mis' 'after two days', where it is placed after substantives (FUF 18 201; (f. on the contrary Wichmann FUF 16 151--). The Vogul noun suffix -la\%, which is a loan from Tatar. occurs in Tavda and Konda dialects also as an independent word (see further Liimola FUF 30 2 $71-$-). In American English the substantive ade 'fruit juice' has been abstracted from words like orangeade, lemonade (W. Wartburg E 78). Not only suffixes or postpositions but new nouns, too. can originate throurh secretion. As a intentional method this has been emplored especially in Hungarian language reform where it is called elcomas 'abstraction, back-formation'. Substantives in particular are often abstracted from verbs. E.g. from the verb angumol-ni to support' (cf. gyamol the support') the substintive aydum 'trustee' his been created. from the verb abraz-ni to depict' (abraz face') abra 'figure' lats been abstracted. Similar secretion also occur's in Hungarian dialects, e.g. from the verb sétal 'to walk' oriminates séta 'a walk" (LS 161--, 282--; further Simonyi Nỵ 11).

Instances of extension of suffix and secretion from the history of languages which so far have been presented in literature prove, of course, that suffixes can originate in this way if the languages already have a system of corresponding frammatical categories and suffixes. However, how might the grenesis of derivatimal suffixes through secretion be conceived at a stage of linguage development where no affixes and corresponding grammatical categories existed at all? Secretion 
presupposes the association of the word ending with a certain meaning or function. Two possibilities may be assumed regarding the rise of such associations.

(1) The word ending has two different phonemic forms one of which subsequently acquires a special meaning, viz. the function of a derivational suffix. E.g. it may be assumed that owing to phonetic conditions depending on the position of the word in the sentence, certain sound changes may come about in the final part of the word, such as assimilations (sandhi), consonants that avoid hiatus, as has been assumed regarding e.g. suffixes $-n$ and $-i,-j$. and the loss of sounds, etc. In different conditions different changes take place or the word remains unchanged. As a result the final part of the word has two (or more) different forms (thus a word may have one form when it precedes a word beginning with a rowel, and another form when it precedes a word which begins with a consonant) of which one later on adopts the function of a derivational suffix.

(2) The genesis of derivational suffixes may result from the "classifying instinct" (see above 178-). Such genesis of suffix may have proceeded from a single word, as has been proved by Jespersen's example of the origin of cat names in the language of a child. This process might be represented by the following plan. If e.g. an object or animal (e.g. cow) has been called $B_{1}+s$ (e.g., punik a red cow) then, following this pattern, other objects or animals of the same kind are later on called $B_{2}+s, B_{3}+s$ (e.g. kü̈̈dik 'a cow with a white stripe', päitsik 'a cow with white head')' etc. In this way the suffix $-s$ (in our example the suffix -ik denoting cow names) has sprung into existance.

\section{The Original Meaming of Suffixes.}

With the problem of the origin of suffixes is connected that of their original meaning. It is evident that if the primary

1 These examples are given here only as symbols, the phonemic form of stems and suffixes of these words has no language historical value. 
derivational suffixes originated by (semantic) agglutination, then they had some original meaning corresponding to the meaning of the word from which they originated (cf. Beronka LK 127-). If derivational suffixes originated from deictic particles or pronouns, then a development is feasible in which their original meaning weakened and they acculired a new meaning from the sentence connections, as e.g. Ludwir and Ravila have delineated this process (cf. also Bárczi TA $1 \pm 1$, and on the original meaning of the locative $-n a$, Collinder CAJb 24: 3-4 8-). Nevertheless, Ravila's assumption that the original function of suffixes was abstract, viz. that of connecting the words with each other, and that they were a kind of very ancient elements of construction, can scarcely be accepted as probable. This, of course, does not mean that derivational suffixes may not, to a certain extent, have acquired their meaning either through the so-called stem irradiation (cf. M. Bréal ES 39-, Zsirai CSLE 30 880, Brugmann $\mathrm{K} \mathrm{313-)}$ ) or from the sentence connections (cf. Klemm ME 155-, Ravila Vir. 1945 150).

If derivational suffixes originated by secretion then naturally they had, as inseparable parts of the stem, originally no separate meaning. But if secretion has come about as a result. of the "classifying instinct", in the way delineated above. the suffix originated through it had a certain original meaning. since it denoted the names of certain objects or beings of the same kind. Later on the suffix that had originated in this way, may also have spread to other groups of words. This spreading of suffixes to new word groups may have taken place through such a net of associations as Wundt has assumed pegarding the spreading of case forms (s $\mathrm{II}^{3} 125$, cf. Bréal ES 225-). The genesis of suffixes through secretion as well as their subsequent spreading to word groups presupposes a certain meaning having been associated with them, since otherwise neither secretion nor spreading would be thinkable. The meaning of the suffix may naturally change later on.

What the primary meaning of the old more extensicely used suffixes was will, perhaps. never be established with certainty. Only most general assumptions may be made con- 
raphing the period in which the suffix has already spread to a wreiter number of words outside its original area of distribution. As the distribution and meaning of suffixes has not originated through logical deduction, but through a net of associations, then in the beginning the meaning may have been complex and logically undifferentiated, though not abstract. It may be assumed that it, similarily to phenomena in the languages of primitive peoples, was of concrete character, though diffuse (ef. what Oertel and Morris say about the ariginal complex notions HS 16 113-).

Taking into account the phenomena occurring in the langlayes of primitive peoples, as well as the later development of the meaning of $\mathrm{FU}$ suffixes. it appears possible that a great part of those derivational suffixes from which later on local cases evolved, had in the beginning a local meaning from which subsequently may have developed the meanings of arjective, genitive, plural and of local cases. Czermak says: "Fanst man alle jene lautlichen Zeichen die die rrimmatischen Beziehungen ausdrücken schärfer ins Auge, so erkennt man alsbald, dass, ebenso wie bei den "Wörtern", durch ihre heutigen Bedentungen letzten Endes etwas Konkret-sinnliches durchschimmert". Czermak maintains further that the purely sensual is something local. and that mede Vorstellung. auch eine sprachliche. setzt ein Vorstellen der Dinge im Raume vor das Aluge volaus" (Fest. Meinhof $204-$, cf. also H. Jensen dutes I 179, H. P. Blok ON 75-; cf. on the contrary Delbrück (is 133).

It may be assumed that another ancient catecory of suffixes, besides the local. are the diminutive suffixes (cf. Mägiste I('LT B 12: 2 223). In principle there is nothing strange in assuming that the original meaning of many FU primary suffixes was diminutive (cf. also Lehtisalo PUA 3). (iyörke is even of the opinion that the original meaning of all Uralic. nominal suffixes was diminutire, from which all other meanings have developed: nomen possessoris. nomen possessi. compillative, etc. (WL 81). Ravila says about the opinion accordingr to which $-m(a),-t(a),-j(a),-n(a),-\beta(a),-r(a)$ and other dererbal noun suffixes are diminutive suffixes: "It would be most curious if there really had been a time when an astoni- 
shingly large number of different suffixes were emplnyed for denoting "the small" "(Vir. 1945 150). The situatinn. however. becomes more natural if we assume, proceeding from the secretion theory, that every diminutive suffix was originally used for a small class of words only. Thus one ending may have been used for denoting small ressels. another for small insects, a third for hirls. still others for plints. fishes and other classes of animils and objects. This, of course, does not mean that. e.r. all the suffixes discussed above really have developed from a diminutive meaning. ('f. in this connection also Hakulinens opinion about the development of the local meaning from the diminutive as regards the suffix -l(a) (SKR I 112).

As regards both local and diminutive suffices it may be assumed that in some instances their phometic form may be due to sound symbolism (about lucal suffixes (f. Jensen loc.e.) Thus it is possible that the original meaning of e.g. FL suffix $-i \sim-j-$ was diminutive, not adjective (cf. T. C. Aminoff Suomi II: 9 258-. Szinnyei FUS 87. Märiste op.c. 222. Cotila Vir. $1945333)$, as the sound symbolic diminutive shade of the vowel $i$ occurs in many languages (ef. e.g. .Jespersen $L, g$ to2 . Mä̈riste op.c. 210). Even if we assume that $-i$, $-j$ - or some other suffix might have alopuired its phometic character through sound symbolism. this does not mean that the diminutive moment alone was associated with that suffix. It maly be assumed that the suffix soon alsu sprearl to words where it did not have a diminutive meaninge (cf. also (jyörke WU 81) so that the suffix alequired a complex meaning.

The erenesis of the suffix, its spreading and sulsequent development must be kept apart. In the later development of the suffix the formation of a more or less distinctly drefined meaning, resp. meanings may be observed (cf. Certel-Morris HS 16 94, 114-, 'Trombetti EA 249-, ('uny EP 276-). When a suffix has berome phonemically differentiated, like e.g. $-j(a),-n(a) .-f(a)$ and almost all $\mathrm{FU}$ primary derivational suffixes, their meaning has also become differentiated, i.e. a special phonemic variant also has a special meaning of its own (cf. e.g. Finnish $-i \sim-j a,-n \sim-n a$ ). 
At the present stage of linguistic research the explanation of the origin and original function of the suffixes has to be limited to hypothetical assumptions only. The task of the present paper has been especially to show that, besides agglutination. secretion and adaptation have also to be reckoned with to a considerable extent. Even if the etymology of some $\mathrm{FU}$ suffixes should be explained in a different way in the future, which is probable, it will not destroy the principle of the standpoint which has been presented here.

V. Tauli.

\section{Abbreviations.}

Actes $=$ Actes du congrèz international de linguistes.

$\mathrm{ACL}$ T Acta et Commentationes Lniversitatis Tartuensis.

$\mathrm{AL}=$ Acta Linguistica (Copenhagen).

ALH = Acta Linguistica Academiae Șcientiarum Hungaricae.

$A M=$ Asia Major

$\mathrm{AS}=$ African Studies.

ASSF = Acta Societatis scientiarum Fennicae.

$A S t=$ Asiatische Studien.

$A t t i=A t t$ del $I I I$ congresso internazionale dei linguisti. Firenze 1935.

$A E^{+} F A=$ Annales Lniversitatis Fennicae tboensis.

BA = Budenz-Album. Budapest 1884 .

Bacot GTL = Bacot Jacques, Grammaire du tibètain littéraire. I-II. Paris 1946--1948.

Bárczi TA = Bárczi Géza, A Tihany apátság alapitólevele mint nyelvi emlèk. Budapest 1951.

Beronka LK $=$ Beronka Johan. Lappische Kasusstudien. I-II. Oslo $1937-1940$.

BI $=$ Bulletin Linguistique.

Bloch SGLD = Bloch Jules, Structure grammaticale des langues dravidiennes. Paris 1946.

Bréal $\mathrm{ES}=$ Bréal Michel. Essai de sémantique. Paris $1921^{5}$.

Brockelmann Gr = Brockelmann Carl. Grundriss der vergleichenden Grammatik der semitischen Sprachen. I-II. Berlin 1908-1913.

Brugmann $\mathrm{K}=$ Brugmann Karl, Kurze vergleichende Grammatik der indogermanischen Sprachen. Strassburg 1902-1904.

Budenz LA = Budenz József, Az ugor nyelvek összehasonlitó alaktana. Budapest $1884-1894$.

Caldwell GrD $=$ Caldwell Robert, A Comparative Grammar of the Dravidian or South-Indian Family of Languages. London $1913^{3}$. 
Castrén JOKS = Castrén M. Alexander, Versuch einer jenissei-rostjakischen und kottischen sprachlehre. St. Petersburg 1858 .

- SamGr $=$ Grammatik der samojedischen Sprachen. St. Petershurg 1854.

CLSE = Commentationes Litterarum Societatis Fsthonicae.

Conf. = Conférences de L'Institut de Linguistiqute de I.'I 'niversité de Paris.

Cuny EP = Cuny Albert. Etudes prégrammaticales. Paris 19:24.

Delbrück GS = Delbrück P.. Grundfragen der Sprachforschung. Strassburg 1901 .

Dempwolff GrJ = Dempwolff Otto. Grammatik der Jahèm-Sprache auf Neuguinea. Hamburg 1939.

Donner $G V^{r}=$ Donner O.. Die gegenseitige Verwandtschaft der finnischugrischen Sprachen. Helsingfors 18:9.

Drexel LWS $=$ Drexel Albert. Lrsprung und Wesen der sprache. I-II . Zürich 1951-1952.

Dumézil IGC = Dumézil Georges, Introduction à la grammaire comparée des langues caucasiennes du nord. Paris 1933.

$\mathrm{EFr}=$ Encyclopédie Française.

$\mathbf{E} \mathbf{K}=$ Eesti heel.

Evsev'ev OMG = Evsever M.F.. Osnovy mordovskoj grammatiki. Moskva 1928.

Fest. Meinhof $=$ Festschrift Meinhof. Hamburg 1927.

Fest. Qvigstad = Festskrift til Rektor J. Qvigstad. ()slu 1928.

Finck HS $=$ Finck Franz Nikolaus, Iie IIauptỵen des sprachbaus. Leipzig 1910.

$\mathrm{FL}: \mathrm{F}=$ Finnisch-ugrische Forschungen.

Gabain ATG = Gabain A., Alttürkische Grammatik. Leipzig 1941.

Gatschet $\mathrm{KI}=$ Gatschet Albert Samuel. The Klamath Indians of Southwestern Oregon. Washington 1890.

Gavel GrB = Gavel Henri - Lacombe Georges. (irammaire basque. I-II. Bayonne 1929-1937.

Genetz SP = Genetz Arvid. Suomen partikkelimuodot. Helsingissä 1890.

Grasserie $\mathrm{C}=$ Grasserie Raoul de la, Des relations grammaticales con sidérées dans leur concept et dans leur expression ou de la catégorie des cas. Paris 1890.

Gray FL = Gray Louis II.. Foundations of Language. New York 1939. Grönbech TS I = Grönbech $\mathrm{K}$.. Der türkische siprachbau. I. Kopenhagen 1936.

Györke WU = Györke J., Die wortbildungslehre des uralischen. Tartu 1934.

$\mathrm{HAIL}=$ Handbook of American Indian Languages. I- IV. Washington -Glückstadt-Hamburg-New-York 1911-1941.

Hakulinen SKR = Hakulinen Lauri, Suomen kielen rakenne ja kehitys. I- II. Helsingissä 1941-1946. 
Hirt HIS = Hirt Herman. Die Hauptprobleme der indogermanischen sprachwissenschaft. Herausgegeben und bearbeitet von Ielmuth Arntz. Halle; Saale 1939.

- IG = Indogermanische (irammatik. I-VII. HeideJberg 1927-1937. Horger MIT = Ilorger Antal, A magyar igeragozas története. Szeged 1931.

HA' = Harrard sludies in Classical Philology.

IF = Indogermanische Forschungen.

JaM = Jazyk i Mỳslenie.

Jespersen Lg = Jespersen Otto, Language, its Nature. Development and Origin. London 1922.

J.FOu = Journal de la Socièté Finno-ougrienne.

Karst GrKA $=$ Karst Josef. Historische Grammatik des KilikischArmenischen. Strassburg 1901.

Kettunen $\mathrm{LW}=$ Kettunen Lauri, Iivisches wörterbuch mit grammatischer einleitung. llelsinki 1938.

$-\mathrm{VK} \mathrm{I}=$ Vatjan kielen äannehistoria. Helsinki $1930^{2}$.

-- VLT = Vepsän murteiden lauseopillinen tutkimus. Helsinki 1943 (IISFOU 86).

Klemm MTM = Klemm Antal, Magyar történeti mondatlan. Budapest $1928-1942$.

$-\mathrm{ME}=\mathrm{A}$ mondatlan elmélete. Budapest 1928.

Koppelmann ES = Koppelmann Heinrich. Die Eurasische Sprachfamilie. Heidelberg 1933.

lisz = Keleti szemle.

$\mathrm{KTT}=$ Kultuuri ja teaduse teilt. Tartu 1932.

Kurylowicz EI I = Kurylowicz Jerzy, Etudes indoeuropeennes. I. Kraków 1935.

$\mathrm{L}, \mathrm{g}=$ Language.

Lehtisalo PLA = Lehtisalo T., Ïber die primären urumalischen ableitungssuffixe. Ilelsinki 1936 (MFFOu ;2).

$\mathrm{I} . \mathrm{XI}=$ Les langues du monde. Paris $1924^{1}$, 1952․․

Lorimer $\mathrm{BL}=$ Lorimer D.L.R.. The Burushaski Language. I. Oslo 1935.

Ludwig -nen = Ludwig Alfred. Über die nominativbildung -nen im Finnischen (-ne im Ehstnischen) von nominalstämmen auf -se (-si). Aus den sitzungsberichten der königl. böhm. Gesellschaft der Wissenschaften. (1884).

- AoA = Agglutination oder adaptation? Prag 18:3.

Malinowski MOM = Malinowski Bronislaw, The Problem of Meaning in Primitive Languages in: Ogden C.R. - Richards I. A., The Meaning of Meaning, London $1936^{4}, 296-$.

Mark $P S T$ Mark Julius, Jie Possessivsuffice in den uralischen sprachen. I. Helsinki 1925 (MSFOu 54).

MEK = Emlékkönṿ Melich János hetvenedik születésenapjára. Budapest 1942 . 
Meinhof PGr = Meinhof Carl. (irundzüge einer vergleichenden grammatik der Bantusprachen. Hamburg $1948^{\circ}$.

- EFS =- Die Entstehung flektierender Fiprachen. Berlin 1936.

$\mathrm{MNy}=$ Magrar Nyelv.

MSFOu = Mémoires de la tiocieté Finno-ougrienne.

MSL = Mémoires de la Société de linguistique de Paris.

MTAK = A Magyár Tudományos Akadémia Nyelv-és Irodalomtudumánỵi Osztálỵának Közleménỵei.

$\mathrm{X}=$ Népünk es Nyelvünk.

$\mathrm{NT}=$ Norsk Tidsskrift for s.progvidenskap.

$\mathrm{Ny}=$ Nyelvtudomány.

$\triangle y K=$ Nyelvtudományi Közlemények.

Nyr = Mag̣ar Nyelvör.

$\mathrm{XyT}=$ Nyelvészeti Tanulmányok.

Oc $=$ Oceania.

Oertel IsL = Oertel IIanns. I.ectures on the study of language. NewJork 1902.

$0 \mathrm{~N}=$ Orientalia Neerlandica. A Volume of Oriental studies. Leiden 1948.

Patkanow LFSO = Patkanow S. - Fuchs D. R.. Laut- und Formenlehre der süd-ostjakischen Dialekte. Budapest 1911.

Poppe GWM = Poppe Nicholas, Crrammar of Written Mongolian. Wiesbaden 195'́t.

- KIIG = Klaalkla-mongolische Grammatik. Wiesbaden 1951.

- $I I=$ Materialy dlja issledovanija tungusskogo jazyka. Leningrad $192 \%$

Ramstedt E II = Ramstedt G.J.. Einführung in die altaische sprachwissenschaft. II. Helsinki 1952 (MSFOU 104: 2).

Royen $\mathrm{XKS}=$ Royen Gerlach, Die nominalen Klassifikations-Sisteme in den sprachen der Erde. Mödling bei Wien 1929.

sajir $\mathbf{L}=$ Sapir Edward. Language. New-York 1921.

icr. Tromb. = Scritti in onore di Alfredo Trombetti. Milano 1938.

Setälä SKL $=$ Setälä E. X.. Nuomen kielen lauseoppi. Helsingissä 192210.

- TuM = Zur Geschichte der Tempus- und Modusstammbildung in den finnisch-ugrischen sprachen. Helsingfors 1886.

- $\ddot{\mathrm{H}} \mathrm{I}=$ Yhteissuomalainen äännehistoria. Helsingissä 1899.

Simonyi TMYy = Simonyi Zsigmond. Tüzetes magyar nyelvtan. I. Budapest 1895 .

- IS = Die ungarische Sprache. Strassburg $190 \%$.

$S \mathrm{Ja}=$ Sovetskoe jaz̧koznanie.

sjögren LGr = s̈jögren Joh. Andreas, livische Grammatik nehst sprachproben. Sit. Petersburg 1861.

SKAW = Sitzungsberichte der Kaiserlichen Akademie der Wissenschaften. Philosophisch-historische Classe. Wien. 
Simedt $S$ M II = Smedt A. de - Mostaert A., Le dialecte Monguor. II: Grammaire. Peking 1945.

$\therefore \mathrm{O}=$ Studia Orientalia.

Specht LID = Specht Franz. Der Lisprung der indogermanischen Deklination. Göttingen 1944.

SSLF = Språkvetenskapliga Sällskapet i Lppsala Förhandlingar.

Steinitz OGr = Steinitz Wolfgang, Ostjakische Grammatik und Chrestomathie. Leipzig $1950\left({ }^{2}\right)$.

Szinnyei FUS = Szinnyei Josef, Finnisch-ugrische Sprachwissenschaft. Berlin-Leipzig $1922^{2}$.

- NyH = Magyar Nyelvhasonlitás. Budapest 1927 .

Sahmatov MÉs = Sahmatov A. A., Mordorskij étnografičeskij sbornik. S.-Peterburg 1910.

$\mathrm{TP}=$ T'oung Pao.

Trombetti $\mathbf{E G}=$ Trombetti Alfredo, Elementi di glottologia. Bologna $1922-1923$.

TS = Iso Tietosanakirja.

$\mathrm{UAJb}=$ Liral-altaische Jahrbiicher.

$\mathrm{LJb}=$ Lngarische Jahrbücher.

Cotila KPS = Uotila T. E., Zur Geschichte des konsonantismus in den permischen Sprachen. Helsinki 1933 (USFOu 65).

UI $\AA=$ Uppsala Lniversitets Årsskrift.

[ZZ 2 = Leningradskij Gosudarstvennyj Ordena Lenina I'niversitet. Vostočnyj Institut. ¿cenye zapiski. Serija vostokovečeskih nauk. Vypusk 2: Sovetskoe finnougrovedenie 1 (1943).

Vir. =- Virittäjä.

Wartburg $\mathrm{E}=$ Wartburg W., Einführung in Problematik und Methodik der Sprachwissenschaft. Halle (Saale) 1943.

WBKL = Wiener Beiträge zur Kulturgeschichte und Iinguistik.

Weske VGFS $=$ Weske Michael, Entersuchungen zur vergleichenden Grammatik des finnischen Sprachstammes. Leipzig 1873.

Westermann WE $=$ Westermann Diedrich, Der Wortbau des Ewe. Abhandlungen der Preussischen Akademie der Wissenschaften 1943, Phil.-hist. Kl. nr 9.

Whitney LGL = Whitney William Dwight, The Life and Growth of Language. London 18:5.

Wickman FOUL = Wickman Bo. The Form of the Object in the Cralic Languages. Uppsala 1955.

Wiedemann MGr = Wiedemann F.J.. Grammatik der ersa-mordwinischen Sprache. st. Petersburg 1865.

- sGr = Grammatik der syrjänischen siprache. St. Petersburg 1884.

Winkler IVS = Winkler Heinrich. Iraltaische völker und sprachen. Berlin 1884.

Wulff $\mathrm{ChT}=$ Wulff $\mathrm{K}$.. Chinesisch und tai. København 1934. 
Wundt $\mathrm{S}=$ Wundt Wilhelm, Völkerpsychologie. Die Sprache. I. Leipzig $1911^{3}$.

- 1I. Leipzig $1904^{2}, 1912^{3}$.

ZDMG = Zeitschrift der deutschen Morgenländischen Gesellschaft. $\mathrm{ZSPh}=$ Zeitschrift für slavische Philologie. 